Article

\title{
Solventless Synthesis of Poly(pyrazolyl) phenyl-methane Ligands and Thermal Transformation of Tris(3,5-dimethylpyrazol-1-yl)phenylmethane
}

\author{
Edith Rodríguez-Venegas ${ }^{1}$, Efrén V. García-Báez ${ }^{1}$, Francisco J. Martínez-Martínez ${ }^{2}$, \\ Alejandro Cruz ${ }^{1}$ and Itzia I. Padilla-Martínez ${ }^{1, *}$ \\ 1 Laboratorio de Química Supramolecular y Nanociencias, Instituto Politécnico Nacional-UPIBI, \\ Av. Acueducto s/n Barrio la Laguna Ticomán, Ciudad de México C.P. 07340, Mexico; \\ edith_rove@hotmail.com (E.R.-V.); efren1003@yahoo.com.mx (E.V.G.-B.); alcralmx@yahoo.com.mx (A.C.) \\ 2 Facultad de Ciencias Químicas, Universidad de Colima, Km. 9 Carretera Colima-Coquimatlán, \\ Coquimatlán C.P. 28400, Mexico; fjmartin@ucol.mx \\ * Correspondence: ipadillamar@ipn.mx; Tel.: +52-555-729-6000
}

Academic Editor: Roman Dembinski

Received: 8 February 2017; Accepted: 6 March 2017; Published: 11 March 2017

\begin{abstract}
The solventless synthesis of tris(pyrazolyl)phenylmethane ligands of formula $\mathrm{C}_{6} \mathrm{H}_{5} \mathrm{C}\left(\mathrm{Pz}^{\mathrm{R} 2}\right)_{3}$ $(\mathrm{R}=\mathrm{H}, \mathrm{Me})$, starting from $\mathrm{PhCCl}_{3}$ and 3,5-dimethylpyrazole $\left(\mathrm{Pz}^{\mathrm{Me} 2}\right)$ or pyrazole $(\mathrm{Pz})$ was performed. The sterically crowded $\mathrm{C}_{6} \mathrm{H}_{5} \mathrm{C}\left(\mathrm{Pz}^{\mathrm{Me} 2}\right)_{3}$ is thermally transformed into the bis(pyrazolyl)(p-pyrazolyl)phenylmethane ligand $\mathrm{Pz}^{\mathrm{Me} 2}-\mathrm{C}_{6} \mathrm{H}_{4} \mathrm{CH}\left(\mathrm{Pz}^{\mathrm{Me}}\right)_{2}$. In this compound both $\mathrm{Pz}^{\mathrm{Me} 2}$ rings are linked through the $\mathrm{N}$-atom to the methine $\mathrm{C}$-atom. At higher temperatures, the binding mode of $\mathrm{Pz}^{\mathrm{Me} 2}$ changes from $\mathrm{N} 1$ to $\mathrm{C} 4$. All transformations occurred via quinonoid carbocation intermediates that undergo an aromatic electrophilic substitution on the 4-position of $\mathrm{Pz}^{\mathrm{Me} 2}$. Reaction conditions were established to obtain five tris(pyrazolyl)phenylmethane ligands in moderate to good yields. ${ }^{1} \mathrm{H}$ - and ${ }^{13} \mathrm{C}-\mathrm{NMR}$ spectroscopy and X-ray diffraction of single crystals support the proposed structures.
\end{abstract}

Keywords: thermal synthesis; tris(pyrazolyl)phenylmethane; bis(pyrazolyl)phenylmethane; poly(pyrazolyl)methane; three-bladed propeller; X-ray molecular structure

\section{Introduction}

Poly(pyrazolyl)methane ligands $\mathrm{RR}^{\prime} \mathrm{C}(\mathrm{Pz})_{2}, \mathrm{RC}(\mathrm{Pz})_{3}$ and $\mathrm{C}(\mathrm{Pz})_{4}$ are the neutral analogues of the anionic poly(pyrazolyl)borates [1-3], where Pz can be either an unsubstituted or C-substituted pyrazolyl unit. They are formally derived by replacing the apical borate anionic moiety $[\mathrm{BR}]^{-}$ by the isoelectronic CR group. Trofimenko, in his pioneering work in the mid-1960s, called the poly(pyrazolyl)methane and poly(pyrazolyl)borate ligands scorpionates [4]. They are versatile hard $\mathrm{N}$-donor ligands that can coordinate in a mono-, bi-, or tridentate fashion to a metal center [5]. The coordination, organometallic and related chemistry of tris(pyrazolyl)methane ligands have been reviewed elsewhere [6]. Bis(pyrazol-1-yl)methane ligands, $\left[\mathrm{RR} \mathrm{R}^{\prime} \mathrm{C}(\mathrm{Pz})_{2}\right]$, have been used as synthetic precursors to a subclass of scorpionates called heteroscorpionates $[7,8]$. Their applications in the design and synthesis of metal complexes with a wide range of applications have been recently reviewed $[8,9]$.

Steric and electronic effects modulate the chemical properties of the corresponding coordination and organometallic complexes of poly(pyrazol-1-yl)methane ligands. Small differences in topology, flexibility, donor properties, modes of coordination and decomposition pathways of these ligands, can lead to significantly different properties in their metal complexes. 
Our investigations on iridium organometallic complexes formed using tris(pyrazol-1-yl)methane indicated that the steric effect exerted by this ligand strongly determines the fate of the organic moiety in the coordination sphere of the metal as well as the energetics of the olefinic $\mathrm{C}-\mathrm{H}$ bond activation reactions [10-12].

The chemistry of poly(pyrazolyl)methanes has been relatively underdeveloped. However, this family of ligands can act as more than a simple spectator in the course of the chemical reactions due to the possibility of temporary changes in denticity and its ambidentate nature after the removal of the bridge $\mathrm{CH}$ proton [13]. Furthermore, the significant number of examples confirm that the properties and reactivity of the corresponding metal complexes differ from that of the tris(pyrazol-1-yl)borate analogues.

More recently, the use of poly(pyrazolyl)methanes in supramolecular chemistry has become more frequent. Bis(pyrazol-1-yl)(pyridin-x-yl)methane ligands give rise to a rich variety of complexes and supramolecular frameworks with a wide range of transition metals [14]. The crowded tris(pyrazolyl)methane chelate in a macrobicyclic structure was synthesized in order to create a cavity with well-defined dimensions and shape [15]. Also, aryl-o-substituted-bis(pyrazol-1-yl)methanes $\left(\mathrm{RSPhCH}\left(\mathrm{Pz}^{\mathrm{Me} 2}\right)_{2}\right)$ have been synthesized to give rise to supramolecular microporous structures such as coordination polymers and macrocycles [16]. Other areas of development are catalysis, bioinorganic and biologically inspired chemistry [17]. In this field, the chemistry of Re and Tc complexes anchored by tris(pyrazolyl)methanes have potential relevance in the field of biomedical applications, particularly in radiopharmaceutical research [18].

In general, poly(pyrazolyl)methanes $\mathrm{CH}_{2}(\mathrm{Pz})_{2}, \mathrm{CH}(\mathrm{Pz})_{3}$ and $\mathrm{C}(\mathrm{Pz})_{4}$ have been prepared by treating the pyrazolate salt with $\mathrm{CH}_{2} \mathrm{Cl}_{2}, \mathrm{CHCl}_{3}$ or $\mathrm{CCl}_{4}$ in the presence of phase transfer catalysts. This technique has been particularly exploited to prepare tris(pyrazol-1-yl)methanes of formula $\mathrm{HC}\left(\mathrm{Pz}^{\mathrm{R}}\right)_{3}\left(\mathrm{R}=3,5-\mathrm{Me}, 3-\mathrm{Ph}, 3{ }^{i} \mathrm{Pr}, 3-{ }^{t} \mathrm{Bu}, 3,5-{ }^{i} \mathrm{Pr}\right)$ [19-22]. The metal catalyzed condensation of $(\mathrm{Pz})_{2} \mathrm{E}=\mathrm{O}(\mathrm{E}=\mathrm{C}, \mathrm{S})$ with aldehydes or ketones provides an efficient route to unsymmetrical tris(pyrazol-1-yl)methane ligands. However, similar chemistry is unsuccessful with substituted pyrazolyl rings [23]. The preparation of "mixed" tris(pyrazolyl)methanes with two or three different pyrazolyl rings $\left(\mathrm{HCPz}^{\mathrm{R}}\left(\mathrm{Pz}^{\mathrm{R}^{\prime}}\right)_{2}\right.$ or $\left.\mathrm{HCPz} \mathrm{Pz}^{\mathrm{R}} \mathrm{Pz}^{\mathrm{R}^{\prime \prime}}\right)$ has been achieved by the scrambling of tris(3,5-dimethylpyrazolyl)methane with substituted pyrazoles in acid media [24]. More recently, a third generation of scorpionates with a substituted-aryl ring bound to the carbon bridge of tris(pyrazol-1-yl)methane, has been synthesized starting from trifluoromethylaniline [25]. Methods for synthesizing bis and tris(pyrazol-1-yl)methanes have been recently reviewed [26].

In an effort to contribute to the design of a new and improved synthesis of poly(pyrazol-1-yl)methane ligands, we decided to explore the synthesis without solvent (solventless synthesis) of tris(3,5-dimethylpyrazol-1-yl)phenylmethane (1a) and tris(pyrazol-1-yl) phenylmethane (1b), starting from $\alpha, \alpha^{\prime}, \alpha^{\prime \prime}$-trichlorotoluene $\left(\mathrm{PhCCl}_{3}\right)$ and 3,5-dimethylpyrazole $\left(\mathrm{Pz}^{\mathrm{Me} 2}\right)$ or pyrazole $(\mathrm{Pz})$, (Figure 1). In this sense, thermal treatment [27] as well as sonochemical methods [28], mechanochemistry [29], microwave [30] and infrared [31] irradiation have been used for chemical synthesis driven by the search for new and cleaner synthetic methodologies. To the best of our knowledge, the sterically crowded compounds $\mathbf{1 a}$ and $\mathbf{1} \mathbf{b}$ have never been described before, whereas $\mathrm{PhCCl}_{3}$ has been scarcely used in spite of its similarity to $\mathrm{CHCl}_{3}$. It has been reported as the starting material for the synthesis of the hexadentate N6-donor phenyltris[3-(2-pyridyl) pyrazol-1-yl]methane [32]. 


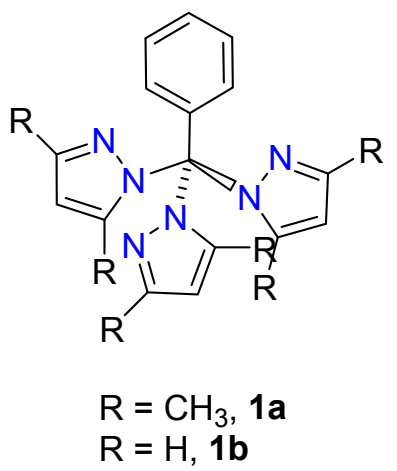

Figure 1. Target compounds $\mathrm{C}_{6} \mathrm{H}_{5} \mathrm{C}\left(\mathrm{Pz}^{\mathrm{Me} 2}\right)_{3}$ (1a) and $\mathrm{C}_{6} \mathrm{H}_{5} \mathrm{C}(\mathrm{Pz})_{3}(\mathbf{1 b})$.

\section{Results and Discussion}

\subsection{Screening Reactions with $\mathrm{Pz} \mathrm{z}^{\mathrm{Me} 2}$}

Since the reaction of pyrazoles with $\mathrm{PhCCl}_{3}$ has been reported to occur in low yields [32], we decided to explore the heating of 3,5-dimethylpyrazole $\left(\mathrm{Pz}^{\mathrm{Me} 2}\right)$ without solvent while varying several different reaction conditions such as temperature, time, stoichiometry and the reaction atmosphere. Results are listed in Table 1 by numbered entries as yields of the isolated products after column chromatography. Initially, the reaction was performed in an open flask equipped with a condenser, the $\mathrm{Pz}^{\mathrm{Me} 2}$ to $\mathrm{PhCCl}_{3}$ ratio was chosen as 6:1, the excess of $\mathrm{Pz}^{\mathrm{Me} 2}$ was used to trap the evolved $\mathrm{HCl}$, the mixture was melted $\left(100{ }^{\circ} \mathrm{C}\right)$ and stirred for $10 \mathrm{~h}$. A stronger base than $\mathrm{Pz}^{\mathrm{Me} 2}$ was not used to trap the evolved $\mathrm{HCl}$ in order to prevent the production of 1,1,2,2-tetrachloro-1,2-diphenylethane as side-product [33]. In the above conditions, compounds 2, 5 and $\mathbf{6}$ were isolated in low yields from the reaction mixture (entry 1) and sublimated $\mathrm{Pz}^{\mathrm{Me} 2}$ was observed on the top of the flask (Scheme 1).

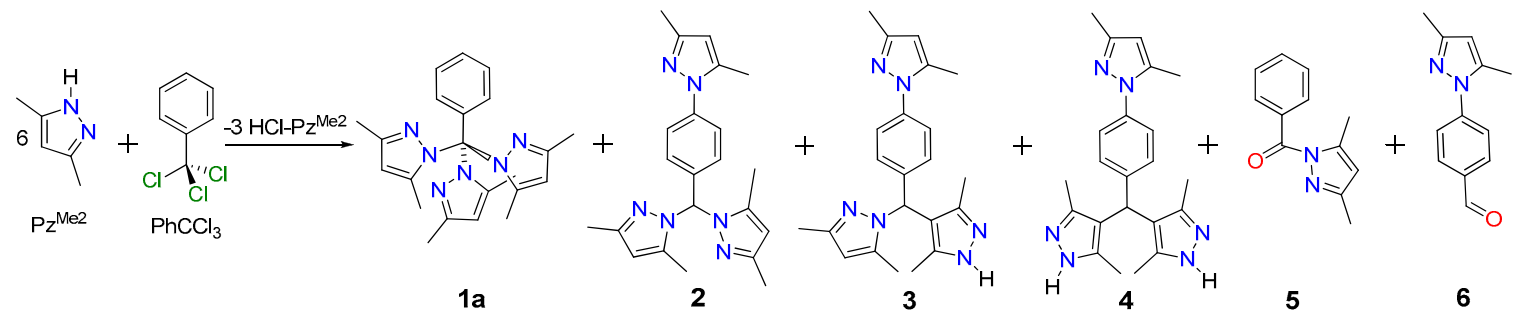

Scheme 1. Thermal reaction of 3,5-dimethylpyrazol $\left(\mathrm{Pz}^{\mathrm{Me} 2}\right)$ with $\alpha, \alpha^{\prime}, \alpha^{\prime \prime}$-trichlorotoluene $\left(\mathrm{PhCCl}_{3}\right)$.

In order to avoid the sublimation of $\mathrm{Pz}^{\mathrm{Me} 2}$ and to improve yields, we used a sealed glass ampoule instead of a flask. The same quantities of reagents were used and heated at $120{ }^{\circ} \mathrm{C}$ for $24 \mathrm{~h}$. In this case, the new product 4 was isolated in low yield (entry 2). The same reaction carried out at $80{ }^{\circ} \mathrm{C}$ for $48 \mathrm{~h}$, leads to only small amounts of compound 5 (entry 3 ). These results suggest the transformation of the target compound 1a into compounds 2 and 4 . However, as compound 1a was not present in any of the last conditions, we carried out the reaction in two steps, the first at $80{ }^{\circ} \mathrm{C}$ and the second at $120{ }^{\circ} \mathrm{C}$ for $24 \mathrm{~h}$ each. In this case compounds 2 (53\%) and the new compound 3 (27\%) appeared as principal products (entry 4). We tried the same reaction lowering the initial reaction time to $24 \mathrm{~h}$ and the $\mathrm{Pz}^{\mathrm{Me} 2}$ to $\mathrm{PhCCl}_{3}$ ratio in 8:1 and 4:1 proportions, but the yields of compounds 2 and 3 were lower (entries 5 and 6, respectively). In all cases, compounds 5 and 6 appeared as oxidation products in the reaction mixture.

To avoid the formation of the oxidation products 5 and $\mathbf{6}$, the reaction was carried out in a one-step reaction, with a $6: 1$ ratio of reactants, at $80{ }^{\circ} \mathrm{C}$ for $24 \mathrm{~h}$ in a sealed ampoule under vacuum. In this case, compound 1a was obtained as the only product in $15 \%$ yield (entry 7 ). The best results to obtain 
compound 1a in 30\% yield were when the reaction was performed in the same reaction conditions but increasing the reaction time to $48 \mathrm{~h}$ (entry 8). Compound 2 was isolated in $70 \%$ yield in the two steps of temperature conditions at $80^{\circ} \mathrm{C}$ and $120^{\circ} \mathrm{C}$ for $48 \mathrm{~h}$ and $24 \mathrm{~h}$, respectively (entry 9 ). Finally, compound 4 was isolated in $14 \%$ yield increasing the temperature to $160{ }^{\circ} \mathrm{C}$ for $72 \mathrm{~h}$ (entry 10).

It is worth mentioning that, to the best of our knowledge, compounds $1 \mathrm{a}-\mathbf{4}$ have not been reported before, compound 5 was reported in 1935 [34] and compound 6 is not known but the pyrazole analogue of 6 has been reported elsewhere [35].

Table 1. Reaction conditions of heating 3,5-dimethylpyrazol with $\alpha, \alpha^{\prime}, \alpha^{\prime \prime}$-trichlorotoluene.

\begin{tabular}{|c|c|c|c|c|c|c|c|c|c|c|}
\hline \multirow{2}{*}{ Entry } & \multirow{2}{*}{ Vessel } & \multirow{2}{*}{ Ratio $^{1}$} & \multicolumn{2}{|c|}{ Temperature $\left({ }^{\circ} \mathrm{C}\right) /$ Time $(\mathrm{h})$} & \multicolumn{6}{|c|}{ Products Isolated Yields (\%) } \\
\hline & & & Step 1 & Step 2 & 1a & 2 & 3 & 4 & 5 & 6 \\
\hline 1 & $\begin{array}{l}\text { Open } \\
\text { flask }\end{array}$ & $6: 1$ & $100 / 10$ & none & - & 11 & - & - & 6 & 10 \\
\hline 2 & $\mathrm{SA}^{2}$ & $6: 1$ & $120 / 24$ & none & - & - & - & 8 & Trace & Trace \\
\hline 3 & $\mathrm{SA}$ & $6: 1$ & $80 / 48$ & none & - & - & - & - & 7 & Trace \\
\hline 4 & SA & $6: 1$ & $80 / 24$ & $120 / 24$ & - & 53 & 27 & - & 6 & Trace \\
\hline 5 & SA & $8: 1$ & $80 / 24$ & $120 / 24$ & - & 48 & 25 & - & 8 & Trace \\
\hline 6 & SA & $4: 1$ & $80 / 24$ & $120 / 24$ & - & 27 & 7 & - & 9 & Trace \\
\hline 7 & $\mathrm{VSA}^{3}$ & $6: 1$ & $80 / 24$ & none & 15 & - & - & - & - & - \\
\hline 8 & VSA & $6: 1$ & $80 / 48$ & none & 30 & - & - & - & - & - \\
\hline 9 & VSA & $6: 1$ & $80 / 48$ & $120 / 24$ & - & 70 & 2 & - & - & Trace \\
\hline 10 & VSA & $6: 1$ & $160 / 72$ & & - & - & - & 14 & - & - \\
\hline
\end{tabular}

\subsection{Effect of Temperature and Time on the Composition of the Reaction Mixtures}

In order to find the appropriate temperature that would favor one of the ligands $1 \mathrm{a}-4$, three reactions were performed using two temperature steps. The first step was fixed at $80{ }^{\circ} \mathrm{C}$ and the second at 100,120 or $160{ }^{\circ} \mathrm{C}$ for $24 \mathrm{~h}$ each. In all cases, the reaction at $80^{\circ} \mathrm{C}$ for $24 \mathrm{~h}$ was used as reference with $30 \%$ composition of compound 1a. The composition of the reaction mixtures was quantified by HPLC and the results are summarized in Table 2 . These experiments and those summarized in Table 3 were performed at a smaller scale (1/5) than the screening experiments summarized in Table 1; thus differences in the composition of the reaction mixtures are explained because of mass dependent conductive/convective heat transfer processes.

Table 2. Composition of the reaction mixture (\%) after two heating steps at three temperatures.

\begin{tabular}{cccc}
\hline \multirow{3}{*}{ Comp. } & \multicolumn{3}{c}{$\mathbf{8 0}^{\circ} \mathbf{C}$ to $\mathbf{T}_{\mathbf{2}}\left({ }^{\circ} \mathrm{C}\right)$} \\
\cline { 2 - 4 } & $\mathbf{1 0 0}$ & $\mathbf{1 2 0}$ & $\mathbf{1 6 0}$ \\
\hline $\mathbf{1 a}$ & 26 & 18 & 0 \\
$\mathbf{2}$ & 11 & 55 & 0 \\
$\mathbf{3}$ & 0 & 12 & 0 \\
$\mathbf{4}$ & 0 & 0 & 11 \\
\hline
\end{tabular}

From the above results, it can be concluded that compounds 2 and 3 are formed at 100 and $120^{\circ} \mathrm{C}$, respectively, at the expense of compound 1a. Compound 4 remained at $160{ }^{\circ} \mathrm{C}$ as the only product in low quantity. These results suggest that compound 1a is successively transformed into compounds $\mathbf{2 - 4}$ with the increase in the temperature of reaction, accompanied by extensive decomposition at $160{ }^{\circ} \mathrm{C}$. As expected, compounds $\mathbf{1 a}$ and 2, with C-N bonds, are produced at lower temperatures; on the contrary, compounds 3 and 4 , with C-C bonds, are favored at higher temperatures.

In an independent experiment, the temperature was fixed at $120^{\circ} \mathrm{C}$ but the course of the reaction was monitored by HPLC for three days. The daily percent composition of the reaction mixture 
is listed in Table 3. A mixture of compounds 1a-4 was found the first day of reaction at $120{ }^{\circ} \mathrm{C}$. In the next two days, the composition of the mixture showed an increase in compound 4 with the corresponding decrement of compounds 1a-3. These results confirm that once formed, compounds 1-3 are consecutively transformed into compound 4 .

Table 3. Composition of the reaction mixture (\%) after heating at $120^{\circ} \mathrm{C}$.

\begin{tabular}{cccc}
\hline \multirow{2}{*}{ Comp. } & \multicolumn{3}{c}{ Heating Time (Days) } \\
\cline { 2 - 4 } & $\mathbf{1}$ & $\mathbf{2}$ & $\mathbf{3}$ \\
\hline 1a & 13 & 8 & 0 \\
$\mathbf{2}$ & 7 & 0 & 0 \\
$\mathbf{3}$ & 5 & 3 & 0 \\
$\mathbf{4}$ & 23 & 35 & 40 \\
\hline
\end{tabular}

Compounds 2-4 contain a built-in entry point for further functionalization, and they could be used as monomers for new polyamines or ligands for the synthesis of MOF's [36]. In addition, both nitrogen atoms of each pyrazole ring in compound 4 are available for further coordination. Suzuki coupling methodology starting from 1-trityl-1H-pyrazol-4-ylboronate pinacol esters and brominated aromatic precursors has been used to achieve this structural feature in the synthesis of oligo-(1H-pyrazol-4-yl)-arenes [37].

\subsection{Reaction between $\mathrm{PhCCl}_{3}$ and $\mathrm{Pz}$}

The reaction of pyrazole and $\mathrm{PhCCl}_{3}$ was performed using the reaction conditions described in entry 9 of Table 1. In these conditions, tris(pyrazolyl)phenylmethane $\mathbf{1 b}$ was isolated in 50\% yield as the only product, Scheme 2. Due to the absence of more products, no other reaction conditions were tested.

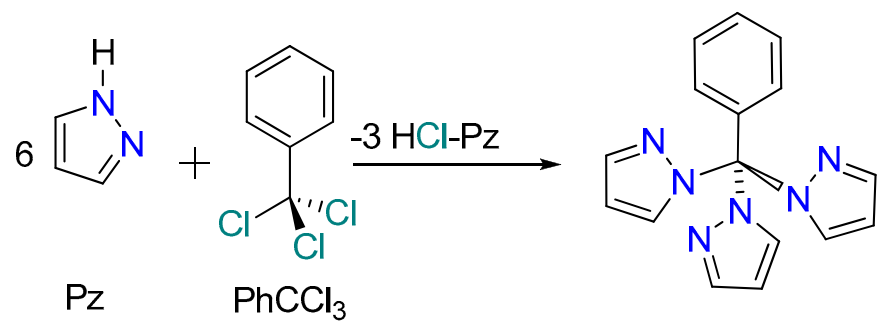

$1 b$

Scheme 2. Thermal reaction of pyrazole with $\alpha, \alpha^{\prime}, \alpha^{\prime \prime}$-trichlorotoluene.

\subsection{Stucture by NMR and IR}

Compounds $\mathbf{1 a}$ and $\mathbf{1 b}$ possess $C 3$ symmetry in agreement with three pyrazole rings bonded to the bridge carbon atom of the former $\mathrm{PhCCl}_{3}$. This was confirmed by the ${ }^{1} \mathrm{H}-\mathrm{NMR}$ spectrum of $1 \mathrm{a}$ that shows two signals for each of methyl groups $(\delta 2.18,1.62)$. One of them appears shielded by $0.4 \mathrm{ppm}$ compared with that of $\left(\mathrm{Pz}^{\mathrm{Me} 2}\right) \mathrm{CH}(\delta 2.09,2.03)$ [21]. The $\mathrm{CH}$ of three $\mathrm{Pz}^{\mathrm{Me} 2}$ rings appeared at $\delta 5.95$. Compound $\mathbf{1 b}$ shows the signals for Pz-ring protons at $\delta 7.73(\mathrm{~d}), 7.52(\mathrm{~d})$ and $6.36(\mathrm{t})$. The typical 1:2:2 pattern for a monosubstituted benzene ring is present in the ${ }^{1} \mathrm{H}-\mathrm{NMR}$ spectra of both compounds. Finally, the bridge carbon atom is at $\delta 94.3$ and 94.4 in ${ }^{13} \mathrm{C}-\mathrm{NMR}$ for $\mathbf{1 a}$ and $\mathbf{1 b}$, respectively.

The ${ }^{1} \mathrm{H}-\mathrm{NMR}$ spectrum of compound 2 shows two sets of signals at $\delta 2.28,2.27$ and 2.26, $2.20 \mathrm{ppm}$ in a 2:1 proportion corresponding to the methyl groups of the $\mathrm{Pz}^{\mathrm{Me} 2}$ rings. Two pyrazole $\mathrm{CH}$ are at $\delta$ 5.86 and $5.98 \mathrm{ppm}$ in agreement with a molecule with $C 2 v$ symmetry. The methine proton and carbon 
atoms appear as a singlet at $\delta 7.65\left({ }^{1} \mathrm{H}\right)$ and $\delta 73.5\left({ }^{13} \mathrm{C}\right)$, very similar to those values reported for $\left(\mathrm{Pz}{ }^{\mathrm{Me} 2}\right)_{2} \mathrm{CHPh}$ [26]. In addition, the presence of signals at $\delta 7.40$ and 6.98 , as doublets, are in agreement with the typical pattern for a $p$-substituted benzene ring. They were assigned to the $m$ - and $o$-protons, respectively, by NOE effect when irradiating the bridge methine $\mathrm{CH}$. This pattern is also observed for compounds 3 and 4 with similar chemical shifts.

The symmetry is lost in compound 3 because the $\mathrm{Pz}^{\mathrm{Me} 2}$ rings are bonded differently to the bridge methine carbon atom. The $\mathrm{C}-\mathrm{N}$ bonded $\mathrm{Pz}^{\mathrm{Me} 2}$ ring, shows signals at $\delta 5.86$ and 105.8 for $\mathrm{H} 4$ and $\mathrm{C} 4$, respectively. No signal corresponding to $\mathrm{H} 4$ was observed and $\mathrm{C} 4$ of $\mathrm{Pz}^{\mathrm{Me} 2}$ ring appeared at $\delta 113.6$ as singlet in the ${ }^{13} \mathrm{C}\left\{{ }^{1} \mathrm{H}\right\}$ NMR spectrum of the C-C bonded ring. In addition, a broad singlet at $\delta$ 144.0, corresponding to the CMe carbon atom of the two tautomers in equilibrium, was observed; the respective $\mathrm{NH}$ appeared at $\delta 7.60$. Also, a singlet appeared for each remaining four methyl carbon atoms. It is worth noting that the chemical shifts of the methine proton and carbon atoms are at $\delta 6.45$ and 57.0, respectively a value in the middle of the corresponding values for compounds 2 and 4 .

In compound 4 , both $\mathrm{Pz}^{\mathrm{Me} 2}$ rings are linked by a $\mathrm{C}-\mathrm{C}$ bond to the bridge methine carbon atom. Some relevant changes in both the ${ }^{1} \mathrm{H}$ - and ${ }^{13} \mathrm{C}$-NMR spectra are appreciated in agreement with its $\mathrm{C} 2 v$ symmetry. The $\mathrm{CH}$ of the pyrazole ring is absent in the ${ }^{1} \mathrm{H}-\mathrm{NMR}$ spectrum, a broad signal at $\delta$ 12 for the NH proton appears instead, as well as a singlet at $\delta 115.7$ in the ${ }^{13} \mathrm{C}\left\{{ }^{1} \mathrm{H}\right\} \mathrm{NMR}$ spectrum, corresponding to $\mathrm{C} 4$ of both $\mathrm{Pz}^{\mathrm{Me} 2}$ rings. Tautomeric equilibrium, typical of $\mathrm{NH}$ pyrazole heterocycles,

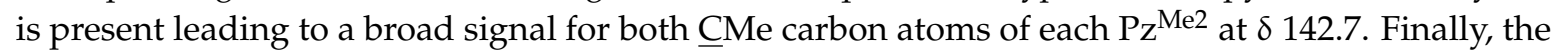
bridge methine proton and carbon atoms are shifted to high fields $(\delta 5.3,39.3)$.

The ${ }^{1} \mathrm{H}-\mathrm{NMR}$ spectrum of compound 5 shows the characteristics set of signals corresponding to a monosubstituted benzene ring as well as a singlet at $\delta 6.06$ and two signals in $\delta 2.63$ and 2.25 for two methyl groups of the $\mathrm{Pz}^{\mathrm{Me} 2}$ ring. The signal at $\delta 168.7$ in the ${ }^{13} \mathrm{C}-\mathrm{NMR}$ spectrum was assigned to a $\mathrm{C}=\mathrm{O}$ group which was confirmed by the presence of an IR stretching band at $1694 \mathrm{~cm}^{-1}$. These spectroscopic data are in agreement with an amide group. The NMR of compound 6 shows the characteristic signal for an aldehyde: a singlet at $\delta 10.04$ in the ${ }^{1} \mathrm{H}-\mathrm{NMR}$ spectrum, and at $\delta 191.4$ in the ${ }^{13} \mathrm{C}-\mathrm{NMR}$ one. The stretching frequency at $1697 \mathrm{~cm}^{-1}$ confirmed the presence of the $\mathrm{C}=\mathrm{O}$ group. The signals in the ${ }^{1} \mathrm{H}-\mathrm{NMR}$ spectrum are consistent with the presence of a $p$-substituted benzene ring at $\delta 7.97$ and 7.67 and, three singlets at $\delta 6.06,2.41$ and 2.31 for the $\mathrm{Pz}^{\mathrm{Me} 2}$ ring.

\subsection{Proposed Reaction Mechanism}

Based on the above results a mechanistic pathway is proposed for the heating reaction of $\mathrm{Pz}^{\mathrm{Me} 2}$ and $\mathrm{PhCCl}_{3}$. A nucleophilic attack of two $\mathrm{Pz}^{\mathrm{Me} 2}$ molecules to carbocation $\mathrm{PhCCl}_{2}{ }^{+}$formed from $\mathrm{PhCCl}_{3}$, give the intermediate carbocation $\mathbf{I}$. The fate of carbocation $\mathbf{I}$ depends on temperature, at $80^{\circ} \mathrm{C}$, the attack of the third $\mathrm{Pz}^{\mathrm{Me} 2}$ leads to compound 1a (Scheme 3, path A). Compound 1a reversibly releases one pyrazole ring to regenerate carbocation $\mathrm{I}$ when temperature is increased to $100{ }^{\circ} \mathrm{C}$. Then, compound 2 is obtained by the attack of the third $\mathrm{Pz}^{\mathrm{Me} 2}$ to the resonance quinonoid aryl carbocation intermediate II (Scheme 3, path B) loosing of one proton to recover the aromatic form. The intrinsic instability of compound 1a could be attributed to the steric repulsion exerted by both phenyl and methyl groups, which favors the breaking of the bridge $\mathrm{C}-\mathrm{N}$ bond to liberate the steric constraint. $\alpha$-chlorobenzyl cations have been reported as intermediates in reactions of hydrolysis [38] whereas radicals or cation radicals are produced only when initiators are added [39]. 


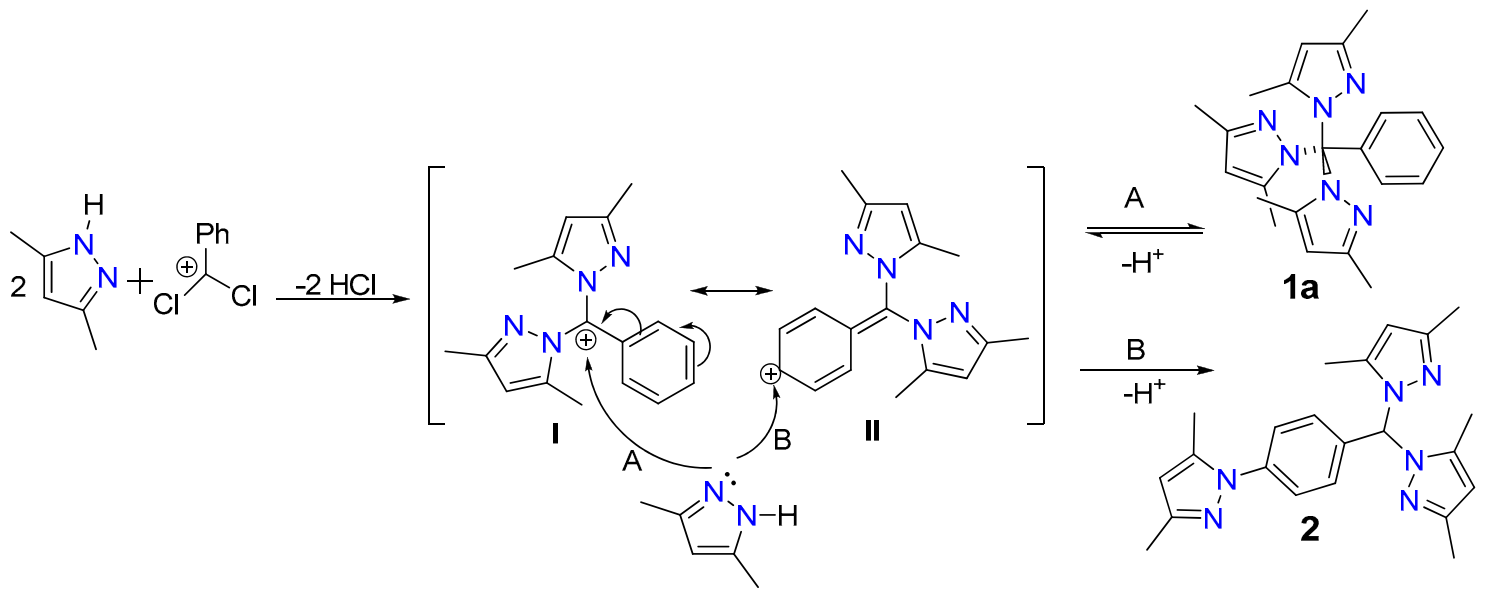

Scheme 3. Proposed mechanistic pathway for the reaction of $\mathrm{Pz}^{\mathrm{Me} 2}$ and $\mathrm{PhCCl}_{3}$.

The synergy of both steric and electronic effects is evident in the reaction of the unsubstituted pyrazole (Pz) and $\mathrm{PhCCl}_{3}$ that produce the stabile compound $\mathbf{1 b}$ as the only product. No decomposition or transformation of $\mathbf{1 b}$ was observed at the temperature of $120^{\circ} \mathrm{C}$. Pyrazole is non-steric constrained and less basic than $\mathrm{Pz}^{\mathrm{Me} 2}$ ( $\mathrm{p} K_{\mathrm{a}}$ values are 2.85 and 14.2 for $\mathrm{Pz}, 4.28$ and 15.1 for $\mathrm{Pz}^{\mathrm{Me} 2}$ ) [40,41]. Compounds 3 and 4 are produced from compound 2. Their formation implies the substitution of $\mathrm{N}$-bonded $\mathrm{Pz}^{\mathrm{Me} 2}$ by C-bonded $\mathrm{Pz}^{\mathrm{Me} 2}$. At $120{ }^{\circ} \mathrm{C}$, compound 2 irreversibly releases one protonated pyrazole ring. This step requires the participation of an electron donating group in the aryl ring to weaken the C-N bond via the formation of the quinonoid carbocation intermediate III, which is stabilized by resonance. The intermediate resonance hybrid form IV performs an aromatic electrophilic substitution (AES) on the 4-position of $\mathrm{Pz}^{\mathrm{Me} 2}$ to form compound 3. The subsequent elimination-substitution of the second pyrazole leads to the formation of compound 4 (Scheme 4). The activating role of the electron donating group in the aryl ring have been demonstrated to be necessary in an elimination-addition mechanism that provides access to tris(pyrazolyl)-toluidines [25]. On the other hand, AES reaction in $\mathrm{Pz}^{\mathrm{Me} 2}$ is reported to occur under mild conditions [42].

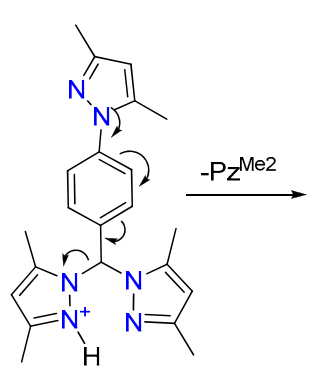

$2-\mathrm{H}^{+}$

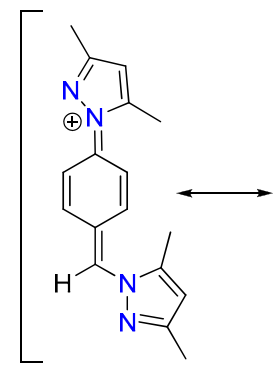

III

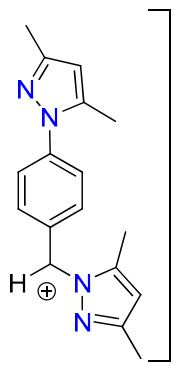

IV
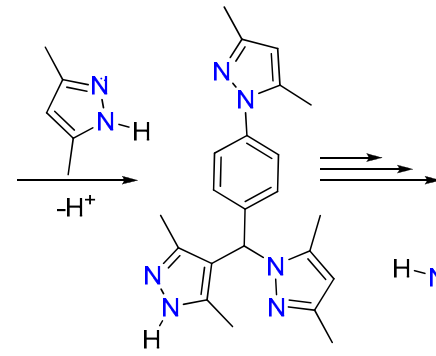

3

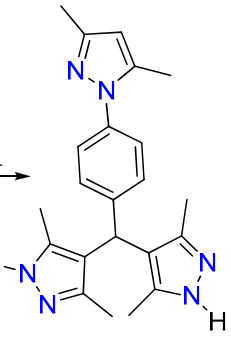

4

Scheme 4. Proposed mechanistic transformation of compound 2 to 3 and 4 .

\subsection{Single Crystal Structures of $\mathbf{1} \mathbf{a}-\mathbf{b}$ and $\mathbf{2}$}

The structures of compounds $\mathbf{1 a}$ and $\mathbf{1 b}$ were unambiguously confirmed by single-crystal X-ray diffraction analysis. Suitable crystals of compound 1a were obtained from hexane solution. Compound 1a crystallized in the monoclinic system with a space group P21/c. The molecular structure is displayed in Figure 2. 


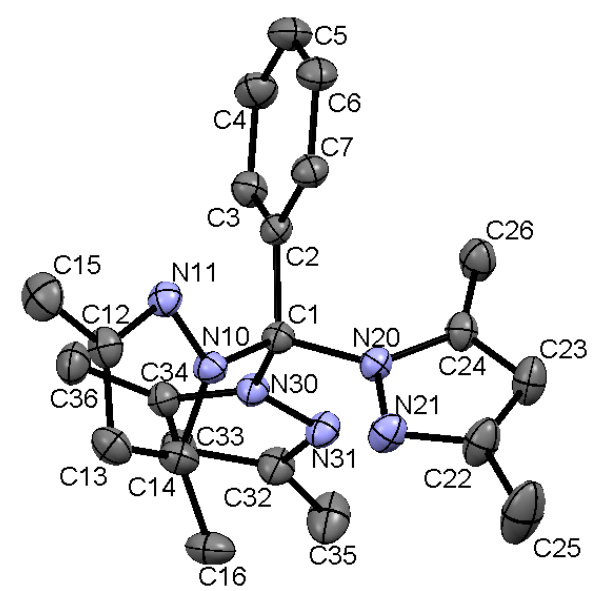

Figure 2. ORTEP perspective of compound 1a at 30\% probability level, hydrogen atoms are omitted for clarity. Selected bonds lengths $(\AA)$ and angles $\left(^{\circ}\right)$ : N10-C1 1.4657(19), N20-C1 1.4725(18), N30-C1 1.479(2), C1-C2 1.532(2), N30-C1-C2 111.47(11), N20-C1-C2 107.84(11), N30-C1-C2 111.75(11), N10-C1-N20 109.86(11), N10-C1-N30 106.48(12), N20-C1-N30 109.43(11), N11-N10-C1 119.04(11), N21-N20-C1 118.72(11), N31-N30-C1 119.76(11).

The geometry around the $\mathrm{C} 1$ bridge carbon atom is nearly tetrahedral with an average N-C-N bond angles of $109(2)^{\circ}$ and the N-C- $\mathrm{C}_{\mathrm{Ph}}$ angle of $110(2)^{\circ}$. The mean C-N and C- $\mathrm{C}_{\mathrm{Ph}}$ bond distances of 1.477(7) $\AA$ and 1.532(2) $\AA$, respectively, are in close correspondence with single bonds (1.493(20), 1.513(14) $\AA$ ) [43]. The three $\mathrm{Pz}^{\mathrm{Me} 2}$ rings adopt a three-bladed propeller structure around the axial phenyl with $\mathrm{R}^{3}-\mathrm{C}-\mathrm{N}-\mathrm{N}$ torsion angles of $\pm 8.97(17)^{\circ}, \pm 101.46(15)^{\circ}$ and $\pm 141.34(13)^{\circ}$. Thus, racemic helical molecules of 1a are found to exist as both left- $(\Lambda)$ and right-handed $(\Delta)$-enantiomers in the asymmetric unit of the crystal lattice. Among several possible conformers, compound 1a adopts a $s p$, $a c$, ac conformation (synperiplanar ( $s p)$, synclinal ( $s c)$, antiperiplanar $(a p)$ and anticlinal $(a c)$ ).

Suitable crystals of compound $\mathbf{1 b}$ were obtained from a saturated solution in AcOEt. Crystals of $\mathbf{1 b}$ crystallize in the orthorhombic system in the acentric $P 2_{1} 2_{1} 2_{1}$ space group. The molecular structure is displayed in Figure 3. Bond distances and angles are very similar to those found in compound 1a (average values): N-C-N bond angle of $110(2)^{\circ}, \mathrm{N}-\mathrm{C}-\mathrm{C}_{\mathrm{Ph}}$ angle of $111(2)^{\circ}$ and $\mathrm{C}-\mathrm{N}$ and $\mathrm{C}-\mathrm{C}_{\mathrm{Ph}}$ bond distances of 1.476(16) $\AA$ and 1.525(5) $\AA$, respectively. Three blades are formed by Pz rings; the values of the $\mathrm{R}^{3}-\mathrm{C}-\mathrm{N}-\mathrm{N}$ torsion angles are $\pm 87.17(4)^{\circ}(\mathrm{sc}), \pm 104.2(4)^{\circ}(a c)$ and $\pm 166.6(4)^{\circ}($ ap $)$.

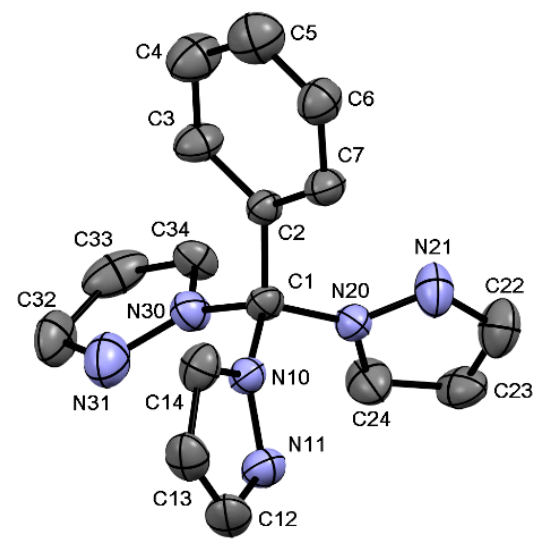

Figure 3. ORTEP perspective of compound $\mathbf{1 b}$ at $25 \%$ probability level; hydrogen atoms are omitted for clarity. Selected bonds lengths $(\AA)$ and angles $\left(^{\circ}\right)$ : N10-C1 1.472(5), N20-C1 1.452(5), N30-C1 1.477(5), C1-C2 1.525(6), N30-C1-C2 111.8(3), N10-C1-N20 109.9(3), N10-C1-N30 107.8(3), N11-N10-C1 119.1(3), N21-N20-C1 120.8(4), N31-N30-C1 126.2(4) 
Since the structures of several ligands $\mathbf{7 - 1 5}$, similar to compounds $\mathbf{1 a}$ and $\mathbf{1} \mathbf{b}$, have been reported [24,25,44-50], a brief comparison between them seems to be appropriate. The structures, $\mathrm{R}^{3}-\mathrm{C}-\mathrm{N}-\mathrm{N}$ torsion angles values and the conformation of pyrazole rings in compounds $\mathbf{1 a}, \mathbf{b}$ and $\mathbf{7 - 1 5}$ are listed in Table 4.

Table 4. Torsion angles and conformation of three bladed propeller structures of general formula $(\mathrm{Pz} 1 \mathrm{R} 2)_{3} \mathrm{C}^{\mathrm{R} 3}$.

\begin{tabular}{|c|c|c|c|}
\hline Comp. & Substituents & Torsion Angle $\left(^{\circ}\right) \mathrm{R}^{3} \mathrm{CNN}$ & Pz $^{\text {R1R2 }}$ Conformation ${ }^{1}$ \\
\hline $1 \mathbf{a}$ & $\mathrm{R}^{1}=\mathrm{R}^{2}=\mathrm{CH}_{3}, \mathrm{R}^{3}=\mathrm{C}_{6} \mathrm{H}_{5}$ & $-8.97(17), 101.46(15), 141.34(13)$ & $s p, a c, a c$ \\
\hline $7[44]$ & $\mathrm{R}^{1}=\mathrm{CH}_{3}, \mathrm{R}^{2}=\mathrm{C}_{6} \mathrm{H}_{5}, \mathrm{R}^{3}=\mathrm{H}$ & $-18.3,133.4,148.6$ & $s p, a c, a c$ \\
\hline $8^{2}[45,46]$ & $\mathrm{R}^{1}=\mathrm{R}^{2}=\mathrm{CH}_{3}, \mathrm{R}^{3}=\mathrm{H}$ & $( \pm) 25(5),( \pm) 116(5),( \pm) 152(5)$ & $s p, a c, a p$ \\
\hline $1 b$ & $\mathrm{R}^{1}=\mathrm{R}^{2}=\mathrm{H}, \mathrm{R}^{3}=\mathrm{C}_{6} \mathrm{H}_{5}$ & $-87.2(4),-104.2(4),-166.6(4)$ & sc, ac, ap \\
\hline $9[25]$ & $\mathrm{R}^{1}=\mathrm{R}^{2}=\mathrm{H}, \mathrm{R}^{3}=o-\mathrm{C}_{6} \mathrm{H}_{4}-\mathrm{NH}_{2}$ & $29.89(13), 87.54(11), 179.85(9)$ & $s p, s c, a p$ \\
\hline $10[25]$ & $\mathrm{R}^{1}=\mathrm{R}^{2}=\mathrm{H}, \mathrm{R}^{3}=p-\mathrm{C}_{6} \mathrm{H}_{4}-\mathrm{NH}_{2}$ & $-25(11),-83(14), 173(7)$ & $s p, s c, a p$ \\
\hline $11[47]$ & $\mathrm{R}^{1}=\mathrm{R}^{2}=\mathrm{H}, \mathrm{R}^{3}=p-\mathrm{C}_{6} \mathrm{H}_{4}-\mathrm{C}_{6} \mathrm{O}_{2} \mathrm{~S}$ & $42.6(7), 73.6(8), 166.4(2)$ & sc, sc, ap \\
\hline $12[48]$ & $\mathrm{R}^{1}=\mathrm{R}^{2}=\mathrm{H}, \mathrm{R}^{3}=p-\mathrm{C}_{6} \mathrm{H}_{4} \mathrm{OH}$ & $-45.02(14),-68.86(14), 173.04(14)$ & $s c, s c, a p$ \\
\hline $13[49]$ & $\mathrm{R}^{1}=\mathrm{R}^{2}=\mathrm{H}, \mathrm{R}^{3}=\mathrm{CH}_{2} \mathrm{OH}$ & $-34.49(13),-62.50(12), 174.56(9)$ & $s c, s c, a p$ \\
\hline $14[24]$ & $\mathrm{R}^{1}=\mathrm{H}, \mathrm{R}^{2}=\mathrm{CH}_{3}, \mathrm{R}^{3}=\mathrm{H}$ & $24.48,27.97,170.87$ & $s p, s p, a p$ \\
\hline $15[50]$ & $\mathrm{R}^{1}=\mathrm{R}^{2}=\mathrm{R}^{3}=\mathrm{H}$ & $13.6,15.7,176.0$ & $s p, s p$, ap \\
\hline
\end{tabular}

${ }^{1}$ Torsion angle from $0^{\circ}$ to $\pm 30^{\circ}$ is called synperiplanar ( $\left.s p\right), \pm 30^{\circ}$ to $\pm 90^{\circ}$ synclinal (sc), $\pm 90^{\circ}$ to $\pm 150^{\circ}$ anticlinal

(ac) and $\pm 150^{\circ}$ to $\pm 180^{\circ}$ antiperiplanar (ap). ${ }^{2}$ Average value of two molecules in the asymmetric unit.

All these molecules are very similar; their bond distances and angles have no evident differences regardless of the steric demand from the substituents in the pyrazole ring or in the apical carbon atom. However, steric effects seem to determine the conformation adopted by pyrazole rings in the three-bladed propeller structure. Compounds 1a and 7, the most crowded, are in such disposition that one pyrazole is in $s p$ and the other two are in $a c$ conformations $(s p+2 a c)$. As long as steric demand is diminished, one ring adopts an ap conformation and the other two are concomitantly twisted to finally adopt the $s p$ conformation $(2 s p+a p)$ in the less crowded compounds 14 and 15 . As expected, substituents in the pyrazole rings exert more steric demand than those located in the apical carbon atom.

Compound 2 crystalized with 0.5 molecules of water in the asymmetric unit as a monoclinic system with a space group C2/c. The crystal structure is shown in Figure 4. Bond distances and angles are very similar to those found in compound 1a (average values): N-C-N bond angle of $111.5(3)^{\circ}$, N-C- $C_{P h}$ angle of $113.3(4)^{\circ}$ and C-N and C- $C_{P h}$ bond distances of 1.455(7) $\AA$ and 1.521(5) $\AA$, respectively. Two blades are formed by $\mathrm{Pz}^{\mathrm{Me} 2}$ rings, the values of the $\mathrm{R}^{3}-\mathrm{C}-\mathrm{N}-\mathrm{N}$ torsion angles are $-105.0(3)^{\circ}$ and $-29.2(5)^{\circ}$ corresponding to $a c, s p$ conformation, respectively.

Two molecules of $\mathbf{2}$ are hydrogen bonded to one molecule of water. One of them forms a pseudo six membered ring $R^{2}{ }_{2}(6)$ [51] through strong $\mathrm{O}-\mathrm{H} \cdots \mathrm{N}$ interactions, with the participation of pyrazole $\mathrm{N}$ atom as the acceptor and by soft $\mathrm{C}\left(s p^{3}\right)-\mathrm{H} \cdots \mathrm{O}$ interactions. The other molecule of 2 is linked to the oxygen atom of the water molecule by pyrazole $\mathrm{C} 4-\mathrm{H}$ as donor (Figure 5). This supramolecular arrangement highlights the acid-base sites in the molecule, in agreement with the proposed mechanism of transformation of compound 2 into compounds 3 and 4 (vide supra). 


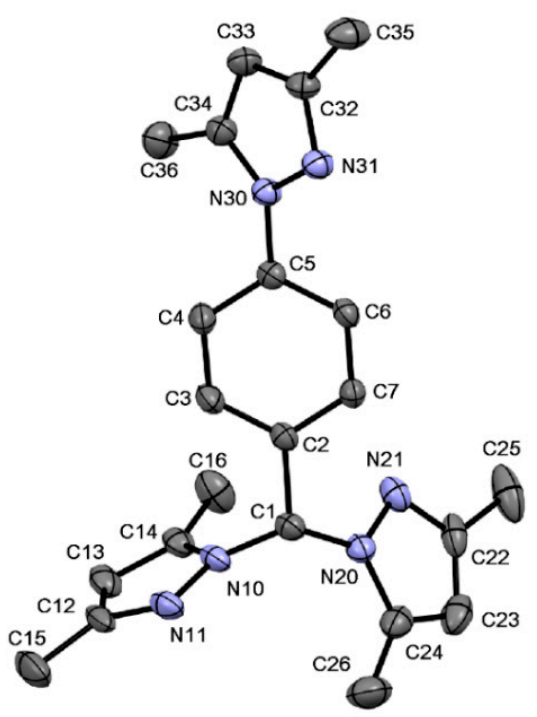

Figure 4. ORTEP perspective of compound 2 at $25 \%$ probability level, hydrogen atoms and the molecule of water are omitted for clarity. Selected bonds lengths $(\AA)$ and angles $\left({ }^{\circ}\right)$ : N10-C1 1.464(5), N20-C1 1.445(5), C1-C2 1.521(5), N10-C1-C2 112.5(3), N20-C1-C2 114.1(3), N10-C1-N20 111.5(3), N11-N10-C1 116.7(3), N21-N20-C1 121.4(3).

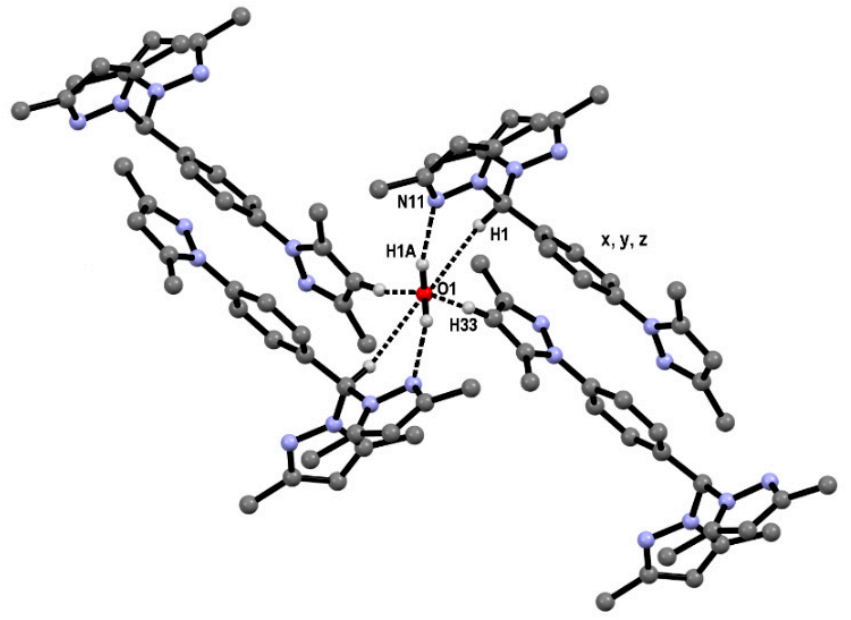

Figure 5. Supramolecular structure of compound 2. Geometry of hydrogen bonding: $\mathrm{H} 1 \mathrm{~A} \cdots \mathrm{N} 11=1.96(6) \AA, \mathrm{O} 1 \cdots \mathrm{N} 11=2.925(4) \AA, \mathrm{O} 1-\mathrm{H} 1 \mathrm{~A} \cdots \mathrm{N} 11=156(6)^{\circ}$ and $\mathrm{H} 1 \cdots \mathrm{O} 1=2.51 \AA$, $\mathrm{C} 1 \cdots \mathrm{O} 1=3.441(6) \AA, \mathrm{C} 1-\mathrm{H} 1 \cdots \mathrm{O} 1=137^{\circ}$ (symmetry code $=-1 / 2+\mathrm{x}, \frac{1}{2}+\mathrm{y}, \mathrm{z}$ ); H33 $\cdots \mathrm{O} 1=2.51 \AA$, $\mathrm{C} 33 \cdots \mathrm{O} 1=3.410(6) \AA, \mathrm{C} 33-\mathrm{H} 33 \cdots \mathrm{O} 1=158^{\circ}$ (symmetry code $=\mathrm{x},-1+\mathrm{y}, \mathrm{z}$ ).

\section{Materials and Methods}

\subsection{Chemicals}

Pyrazole, 3,5-dimethylpyrazole, $\alpha, \alpha^{\prime}, \alpha^{\prime \prime}$-trichlorotoluene and solvents were reagent grade and used as received.

\subsection{Instrumental Methods}

Melting points were measured on an IA 9100 apparatus (Electrothermal, Staffordshire, UK) and are uncorrected. IR spectra were recorded using a 3100 FT-IR Excalibur Series spectrophotometer (Varian, Randolph, MA, USA) equipped with an ATR system. Mass spectra were obtained in a 3900-GC/MS system (Varian, Palo Alto, CA, USA) with an electron ionization mode. Elemental analyses (EA) were 
performed on a 2400 elemental analyzer (Perkin-Elmer, Waltham MA, USA). ${ }^{1} \mathrm{H}$ - and ${ }^{13} \mathrm{C}-\mathrm{NMR}$ spectra were recorded on a Varian Mercury $300\left({ }^{1} \mathrm{H}, 300.08 ;{ }^{13} \mathrm{C}, 75.46 \mathrm{MHz}\right)$ instrument in $\mathrm{CDCl}_{3}$ solutions for compounds 1-6, and in DMSO-d6 solutions for compound 7, $\mathrm{SiMe}_{4}$ as the internal reference was used. Chemical shifts are in ppm and ${ }^{n} J(\mathrm{H}-\mathrm{H})$ in hertz. The chemical shift assignments were performed on the basis of ${ }^{1} \mathrm{H}$ - and ${ }^{13} \mathrm{C}-\mathrm{NMR}$ NOE, COSY and HETCOR experiments. Composition of the reaction mixtures were performed in a Varian $9010 \mathrm{HPLC}$ instrument at $252 \mathrm{~nm}$. A C18 column of $5 \mu \mathrm{m}$ particle size and $25 \mathrm{~cm}$ length and $0.5 \mathrm{~cm}$ wide was used. Elution was achieved with $\mathrm{MeOH} / \mathrm{H}_{2} \mathrm{O}$ mixtures in a 7:3 proportion, unless otherwise specified.

\subsection{X-ray Diffraction Methods}

Single-crystal X-ray diffraction data of molecules $\mathbf{1 a}, \mathbf{1} \mathbf{b}$ and $\mathbf{2}$ were recorded on a D8 Quest CMOS (Bruker, Karlsruhe, Germany) or Nonius Kappa (Rotterdam, The Netherlands) area detector diffractometers with Mo $\mathrm{K} \alpha$ radiation, $\lambda=0.71073 \AA$. A table listing the crystallographic data is provided as Supplementary Material. The structures were solved by direct methods using SHELXS97 [52] program of WinGX package [53]. The final refinement was performed by full-matrix least-squares methods on F2 with SHELXL97 [52] program. $\mathrm{H}$ atoms on C were geometrically positioned and treated as riding atoms, with $\mathrm{C}-\mathrm{H}=0.93-0.98 \AA$, and with $\mathrm{Uiso}(\mathrm{H})=1.2 \mathrm{Ueq}(\mathrm{C})$. The hydrogen atoms of the water molecule were found by Fourier difference and freely refined. The program Mercury was used for visualization, molecular graphics and analysis of crystal structures [54]. The software used to prepare material for publication was PLATON [55]. Crystallographic data for the structures in this paper have been deposited with the Cambridge Crystallographic Data Centre as supplementary publication CCDC numbers 1527853 (1a), 1527852 (1b) and 1527854 (2). Copies of the data can be obtained free of charge on application to CCDC, 12 Union Road, Cambridge CB2 1EZ, UK, (Fax: +44-01223-336033 or E-Mail: deposit@ccdc.cam.ac.uk). Crystals suitable for X-ray analysis were obtained from the saturated hexane solution of compound 1a and from DMSO- $\mathrm{H}_{2} \mathrm{O}$ solution (1:1) of compound $\mathbf{1 b}$. Compound $\mathbf{2}$ slowly crystalized with one molecule of water in the asymmetric unit from the semi-solid remaining after solvent evaporation.

Crystal Data for $\mathrm{C}_{22} \mathrm{H}_{26} \mathrm{~N}_{6}(\mathbf{1 a}, \mathrm{M}=374.5 \mathrm{~g} / \mathrm{mol})$ : monoclinic, space group P21/c (No. 14), $a=10.0680(3) \AA, b=14.6640(3) \AA, c=15.3674(5) \AA, \beta=114.204(3)^{\circ}, \mathrm{V}=2069.35(31) \AA^{3}, \mathrm{Z}=4$, $\mathrm{T}=298(2) \mathrm{K}$, Dcalc $=1.200 \mathrm{~g} / \mathrm{cm}^{3}, 23332$ reflections measured $\left(3.4^{\circ} \leq 2 \Theta \leq 27.5^{\circ}\right), 4632$ unique $($ Rint $=0.046$, Rsigma $=0.048)$ which were used in all calculations. The final R1 was $0.053(\mathrm{I}>2 \sigma(\mathrm{I}))$ and $w R 2$ was 0.125 (all data).

Crystal Data for $\mathrm{C}_{16} \mathrm{H}_{14} \mathrm{~N}_{6}$ (1b, $\left.\mathrm{M}=290.33 \mathrm{~g} / \mathrm{mol}\right)$ : orthorhombic, space group P2 ${ }_{1} 2_{1} 2_{1}$ (No. 19), $a=7.0198(8) \AA, b=14.2693(16) \AA, c=14.6994(17) \AA, \alpha=\beta=\gamma=90^{\circ}, \mathrm{V}=1449.37(3) \AA^{3}, \mathrm{Z}=4$, $\mathrm{T}=293(2) \mathrm{K}$, Dcalc $=1.331 \mathrm{~g} / \mathrm{cm}^{3}, 8182$ reflections measured $\left(2.0^{\circ} \leq 2 \Theta \leq 24.0^{\circ}\right), 2280$ unique $($ Rint $=0.08$, Rsigma $=0.139)$ which were used in all calculations. The final R1 was $0.055(I>2 \sigma(\mathrm{I}))$ and wR2 was 0.1203 (all data).

Crystal Data for $\mathrm{C} 22 \mathrm{H} 26 \mathrm{~N} 6 \cdot 0.5 \mathrm{H}_{2} \mathrm{O}(2, \mathrm{M}=383.49 \mathrm{~g} / \mathrm{mol}):$ monoclinic, space group C 2/c (No. 15), $a=20.9571(15) \AA, b=9.5425(6) \AA, c=21.8515(16) \AA, \beta=103.528(2)^{\circ}, \mathrm{V}=4248.69(22) \AA^{3}, \mathrm{Z}=4$, $\mathrm{T}=100(2) \mathrm{K}$, Dcalc $=1.200 \mathrm{~g} / \mathrm{cm}^{3}, 19257$ reflections measured $\left(2.4^{\circ} \leq 2 \Theta \leq 25.0^{\circ}\right), 3584$ unique $($ Rint $=0.043$, Rsigma $=0.0351)$ which were used in all calculations. The final R1 was $0.089(\mathrm{I}>2 \sigma(\mathrm{I}))$ and wR2 was 0.188 (all data).

\subsection{Synthetic Procedures}

\subsubsection{Open Flask Procedure}

3,5-Dimethylpyrazole ( $\mathrm{Pz}^{\mathrm{Me} 2}, 5.00 \mathrm{~g}, 52.0 \mathrm{mmol}$ ) was placed in a round bottom flask, submerged in a silicon oil bath and heated at $110{ }^{\circ} \mathrm{C}$ with constant stirring. When the pyrazole was molten, 
$\alpha, \alpha^{\prime}, \alpha^{\prime \prime}$-trichlorotoluene $\left(\mathrm{PhCCl}_{3}, 246 \mu \mathrm{L}\right)$ was added dropwise every hour until complete $1.230 \mathrm{~mL}$ $(8.660 \mathrm{mmol})$ had been added. Heating was maintained for $5 \mathrm{~h}$ to obtain a yellow viscous liquid. The products were purified by column chromatography on silica gel using a 6:4 mixture of hexane/EtOAc as eluent (Table 1, entry 1$)$.

\subsubsection{Sealed Ampoule Procedure}

$\mathrm{Pz}^{\mathrm{Me} 2}(5.00 \mathrm{~g}, 52.0 \mathrm{mmol})$ was ground in a mortar and placed into a $10 \mathrm{~mL}$ glass ampoule with $\mathrm{PhCCl}_{3}(0.93 \mathrm{~mL}$ for $8: 1 ; 1.23 \mathrm{~mL}$ for $6: 1$ or $1.85 \mathrm{~mL}$ for $4: 1$ ratio). The ampoules were sealed at room temperature, introduced into a convection oven and allowed to react at the temperature and time indicated in Table 1. The obtained viscous brown colored mixtures were dissolved in $50 \mathrm{~mL}$ of $\mathrm{CHCl}_{3}$ to remove them from the ampoules and subjected to column chromatography on silica gel. Compounds 1-3 and 5-6 were purified using hexane/EtOAc mixtures from 8:2 to 6:4 proportions as eluents.

\subsubsection{Vacuum Sealed Ampoule Procedure}

$\mathrm{Pz}^{\mathrm{Me} 2}(5.00 \mathrm{~g}, 52.0 \mathrm{mmol})$ was ground in a mortar and placed into a $10 \mathrm{~mL}$ glass ampoule with $\mathrm{PhCCl}_{3}(1.23 \mathrm{~mL}, 8.66 \mathrm{mmol}, 6: 1)$. The ampoules were frozen at $-30{ }^{\circ} \mathrm{C}$, sealed under vacuum and then introduced into a convection oven and allowed to react at the temperature and time indicated in Table 1. The reaction mixtures were treated as indicated in Section 3.4.2.

\subsection{Synthesis of Compounds 1-6}

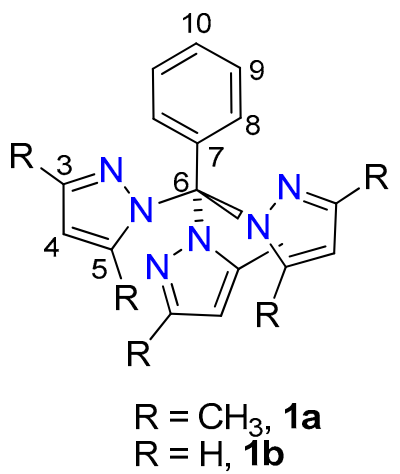

1,1',1"-(Phenylmethanetriyl)tris(3,5-dimethyl-1H-pyrazole) (1a). This compound was synthesized following the procedure described in Section 3.4 .3 heating at $80^{\circ} \mathrm{C}$ for $24 \mathrm{~h}$ (Table 1, entry 8) to obtain $0.975 \mathrm{~g}(2.60 \mathrm{mmol}, 30 \%$ yield $)$ of a white crystalline solid m.p. $=90^{\circ} \mathrm{C}$ after column chromatography. ${ }^{1} \mathrm{H}-\mathrm{NMR}\left(\mathrm{CDCl}_{3}\right): \delta 7.39\left(\mathrm{t}, 1 \mathrm{H},{ }^{3} \mathrm{~J}=6.9, \mathrm{H}-10\right), 7.32\left(\mathrm{t}, 2 \mathrm{H},{ }^{3} \mathrm{~J}=7.0, \mathrm{H}-9\right), 7.02\left(\mathrm{~d}, 2 \mathrm{H},{ }^{3} \mathrm{~J}=7.0, \mathrm{H}-8\right)$, 5.95 (s, 3H, H-4), 2.18, 1.62 (s, 9H each, 6CH $) .{ }^{13} \mathrm{C}-\mathrm{NMR}\left(\mathrm{CDCl}_{3}\right): \delta 146.9(\mathrm{C}-3), 143.9(\mathrm{C}-5), 138.1$ (C-7), 130.5 (C-8), 129.6 (C-9), 127.3 (C-10), 109.1 (C-4), 94.3 (C-6), 14.3, $12.9\left(\mathrm{CH}_{3}\right)$. IR neat $\left(\mathrm{cm}^{-1}\right)$ : $1697(\mathrm{C}=\mathrm{C}), 1562\left(\mathrm{C}_{\mathrm{ar}}\right), 1450,1411,1374,1316,1027,890,716$. EA \% found [calculated for $\mathrm{C}_{22} \mathrm{H}_{26} \mathrm{~N}_{6}$ $\left.\left(374.49 \mathrm{~g} \cdot \mathrm{mol}^{-1}\right)\right]$ : $70.06(70.56, \mathrm{C}), 7.11(7.00, \mathrm{H}), 22.01(22.40, \mathrm{~N})$.

1,1',1"-(Phenylmethanetriyl)tris $\left(1 \mathrm{H}\right.$-pyrazole) (1b). A crystalline solid m.p. $=105^{\circ} \mathrm{C}$ was obtained $(1.95 \mathrm{~g}$, $55 \%$ yield), starting from $4.97 \mathrm{~g}(17.16 \mathrm{mmol})$ of pyrazole and $1.7 \mathrm{~mL}(12.2 \mathrm{mmol})$ of $\mathrm{PhCCl}_{3}$. Procedure 3.4.3 was followed using two temperature steps: $80^{\circ} \mathrm{C}$ and $120^{\circ} \mathrm{C}$ for 48 and $24 \mathrm{~h}$ each, respectively (Table 1, entry 9). The crude product was solubilized in EtOAct and filtered, whereupon compound $\mathbf{1 b}$ crystallized from the solution. ${ }^{1} \mathrm{H}-\mathrm{NMR}\left(\mathrm{CDCl}_{3}\right): 7.73(\mathrm{~d}, 3 \mathrm{H}, \mathrm{H}-3), 7.52\left(\mathrm{~d}, 3 \mathrm{H},{ }^{4} \mathrm{~J}=2.6, \mathrm{H}-5\right), 7.48$ $\left(\mathrm{t}, 1 \mathrm{H},{ }^{3} \mathrm{~J}=7, \mathrm{H}-10\right), 7.41\left(\mathrm{t}, 2 \mathrm{H},{ }^{3} \mathrm{~J}=8.7, \mathrm{H}-9\right), 7.09\left(\mathrm{~d}, 2 \mathrm{H},{ }^{3} \mathrm{~J}=8, \mathrm{H}-8\right), 6.36\left(\mathrm{t}, 3 \mathrm{H},{ }^{4} \mathrm{~J}=2.6,1.7, \mathrm{H}-4\right)$. ${ }^{13} \mathrm{C}-\mathrm{NMR}\left(\mathrm{CDCl}_{3}\right)$ : 141.6 (C-3), 137.6 (C-7), 132.6 (C-5), 130.8 (C-10), 128.9 (C-9), 128.5 (C-8), 106.7 (C-4), 93.4 (C-6). IR (neat, $v / \mathrm{cm}^{-1}$ ): $1682(\mathrm{C}=\mathrm{N}), 1451,1419,1388,1196,1095,1087,864,746$ (Pz out of plane). EA \% found [calculated for $\mathrm{C}_{16} \mathrm{H}_{14} \mathrm{~N}_{6}\left(290.32 \mathrm{~g} \cdot \mathrm{mol}^{-1}\right)$ ]: $66.16(66.19, \mathrm{C}), 4.91(4.86, \mathrm{H}), 28.91(28.95, \mathrm{~N})$. 


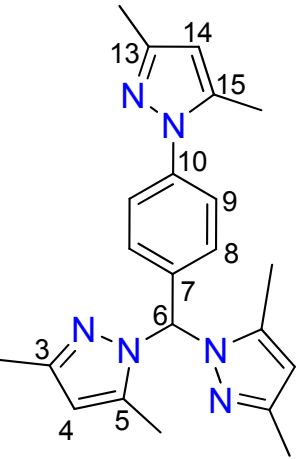

2

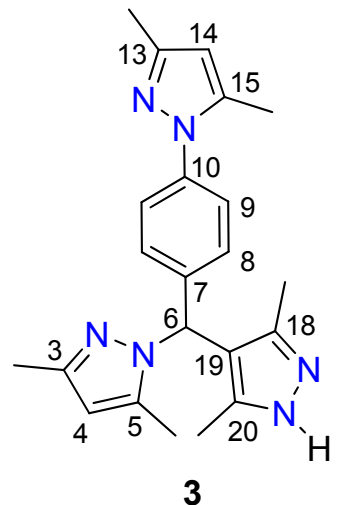

3

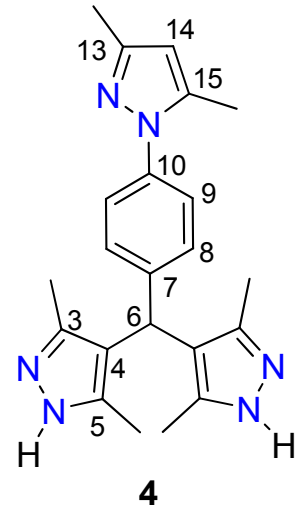

4

1,1'-((4-(3,5-Dimethyl-1H-pyrazol-1-yl)phenyl)methylene)bis(3,5-dimethyl-1H-pyrazole) (2). Synthesized following the procedure described in Section 3.4.3 using two temperature steps at $80{ }^{\circ} \mathrm{C}$ and $120{ }^{\circ} \mathrm{C}$ for 48 and $24 \mathrm{~h}$ each, respectively (Table 1, entry 9). After column chromatography, $2.28 \mathrm{~g}$ (6.09 mmol, 70\% yield) of compound 2 as a viscous yellow liquid which slowly solidified after standing as a yellow solid m.p. $=97{ }^{\circ} \mathrm{C}$ was obtained. ${ }^{1} \mathrm{H}-\mathrm{NMR}: \delta 7.65(\mathrm{~s}, 1 \mathrm{H}, \mathrm{H}-6), 7.40(\mathrm{~d}, 2 \mathrm{H}$, $\left.{ }^{3} \mathrm{~J}=8.8, \mathrm{H}-9\right), 6.98$ (d, 2H, $\left.{ }^{3} \mathrm{~J}=8.8, \mathrm{H}-8\right), 5.98$ (s, $\left.1 \mathrm{H}, \mathrm{H}-14\right), 5.86(\mathrm{~s}, 2 \mathrm{H}, \mathrm{H}-4), 2.28,2.27$ (s, 6H each, $\left.4 \mathrm{CH}_{3}\right)$, 2.26, 2.20 (s, 3H each, 2CH 3 ). ${ }^{13} \mathrm{C}-\mathrm{NMR}: \delta 149.5$ (C-13), 148.8 (2C-3), 141.3 (2C-5), 140.1 (C-15), 139.7 (C-10), 135.8 (C-7), 127.9 (2C-8), 124.6 (2C-9), 107.5 (C-14), 107.2 (2C-4), 73.5 (C-6), 13.9, $13.0\left(4 \mathrm{CH}_{3}\right)$, 13.7, $12.7\left(2 \mathrm{CH}_{3}\right)$. IR (neat, $\left.v / \mathrm{cm}^{-1}\right): 1612(\mathrm{C}=\mathrm{N}), 1556(\mathrm{C}=\mathrm{C}), 1520\left(\mathrm{C}_{\mathrm{ar}}\right), 1417\left(\mathrm{CH}_{3}\right), 750$ (pyrazole out of plane). MS (\%): $374.0(\mathrm{M}+, 3), 279.0$ (100), 183.9 (5), 162.0 (26), 94.8 (12.5). EA \% found [calculated for $\left.\mathrm{C}_{22} \mathrm{H}_{26} \mathrm{~N}_{6}\left(374.48 \mathrm{~g} \cdot \mathrm{mol}^{-1}\right)\right]$ : $70.50(70.56, \mathrm{C}), 7.17(7.00, \mathrm{H}), 21.70(22.44, \mathrm{~N})$.

1,4'-((4-(3,5-Dimethyl-1H-pyrazol-1-yl)phenyl)methylene)bis(3,5-dimethyl-1H-pyrazole) (3). Synthesized following the procedure described in Section 3.4.2 using two temperature steps of $80^{\circ} \mathrm{C}$ and $120^{\circ} \mathrm{C}$ for $24 \mathrm{~h}$ each (Table 1, entry 4$)$ to obtain, after column chromatography, $0.88 \mathrm{~g}(2.35 \mathrm{mmol}, 27 \%$ yield $)$ of a yellow viscous liquid that after a while turned into a beige solid, m.p. $=126{ }^{\circ} \mathrm{C} .{ }^{1} \mathrm{H}-\mathrm{NMR}: \delta 7.60$ (b, 1H, NH), 7.31 (d, 2H, $\left.{ }^{3} \mathrm{~J}=8.5, \mathrm{H}-9\right), 6.91\left(\mathrm{~d}, 2 \mathrm{H},{ }^{3} \mathrm{~J}=8.5, \mathrm{H}-8\right), 6.45$ (s, 1H, H-6), 5.96 (s, 1H, H-14), $5.86(\mathrm{~s}, 1 \mathrm{H}, \mathrm{H}-4), 2.27,2.25,2.20,2.18\left(\mathrm{~s}, 3 \mathrm{H}\right.$ each, $\left.4 \mathrm{CH}_{3}\right), 1.92\left(\mathrm{~s}, 6 \mathrm{H}, 2 \mathrm{CH}_{3}\right) .{ }^{13} \mathrm{C}-\mathrm{NMR}: \delta 149.2(\mathrm{C}-13)$, 147.9 (C-3), 144.0 (C-18,20), 140.0 (C-15), 139.7 (C-5), 139.6 (C-10), 139.0 (C-7), 127.9 (2C-8), 124.8 (2C-9), 113.6 (C-19), 107.2 (C-14), 105.8 (C-4), 57.0 (C-6), 14.0, 13.7, 12.7, $11.5\left(4 \mathrm{CH}_{3}\right), 11.8\left(2 \mathrm{CH}_{3}\right)$. IR (neat, v/cm $\left.{ }^{-1}\right): 1613,1589(\mathrm{C}=\mathrm{N}), 1554(\mathrm{C}=\mathrm{C}), 1519(\mathrm{Car}), 1425\left(\mathrm{CH}_{3}\right), 749$ (pyrazole out of plane). MS (\%): $374.0(\mathrm{M}+, 3), 279.0(100), 94.8(67.5)$. EA \% found [calculated for $\mathrm{C}_{22} \mathrm{H}_{26} \mathrm{~N}_{6}\left(374.48 \mathrm{~g} \cdot \mathrm{mol}^{-1}\right)$ ]: 70.20 $(70.56, \mathrm{C}), 7.10(7.00, \mathrm{H}), 21.82(22.40, \mathrm{~N})$.

4,4'-((4-(3,5-Dimethyl-1H-pyrazol-1-yl)phenyl)methylene)bis(3,5-dimethyl-1H-pyrazole) (4). Synthesized following the procedure described in Section 3.4.3 after heating at $160{ }^{\circ} \mathrm{C}$ for $72 \mathrm{~h}$ (Table 1, entry 10). Excess $\mathrm{Pz}^{\mathrm{Me} 2}$ was sublimed and the remaining solid was stirred twice in $25 \mathrm{~mL}$ of $10 \% \mathrm{NaHCO}_{3}$ solution, decanted, washed twice with $50 \mathrm{~mL}$ of water, filtered and air dried. After column chromatography, $0.460 \mathrm{~g}(1.23 \mathrm{mmol}, 14 \%$ yield $)$ of a pale beige solid which decomposes at $249{ }^{\circ} \mathrm{C}$ was isolated. ${ }^{1} \mathrm{H}-\mathrm{NMR}: \delta 12.0(\mathrm{~b}, 2 \mathrm{H}, \mathrm{NH}), 7.38\left(\mathrm{~d}, 2 \mathrm{H},{ }^{3} \mathrm{~J}=8.0, \mathrm{H}-9\right), 7.13\left(\mathrm{~d}, 2 \mathrm{H},{ }^{3} \mathrm{~J}=7.4, \mathrm{H}-8\right), 6.03(\mathrm{~s}, 1 \mathrm{H}$,

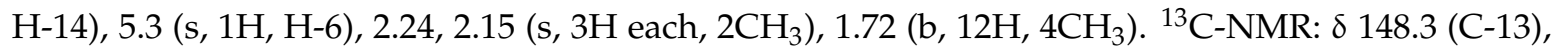
142.7 (b, 2C-5 and 2C-3), 142.6 (C-7), 139.7 (C-15), 138.2 (C-10), 129.6 (2C-8), 124.5 (2C-9), 115.7 (2C-4), $107.6(\mathrm{C}-14), 39.3(\mathrm{C}-6), 14.0,12.8\left(2 \mathrm{CH}_{3}\right), 11\left(\mathrm{~b}, 4 \mathrm{CH}_{3}\right)$. IR (neat, $\left.v / \mathrm{cm}^{-1}\right)$ : $\mathrm{X}(\mathrm{C}=\mathrm{N}), 1558(\mathrm{C}=\mathrm{C}), 1517$ $\left(\mathrm{C}_{\mathrm{ar}}\right), 1413\left(\mathrm{CH}_{3}\right), 760$ (pyrazole out of plane). EA \% found [calculated for $\mathrm{C}_{22} \mathrm{H}_{26} \mathrm{~N}_{6}\left(374.48 \mathrm{~g} \cdot \mathrm{mol}^{-1}\right)$ ]: $69.41(70.56, \mathrm{C}), 7.03(7.00, \mathrm{H}), 21.52(22.40, \mathrm{~N})$. 


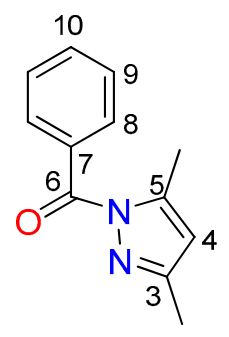

5

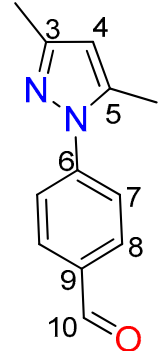

6

(3,5-Dimethyl-1H-pyrazol-1-yl)(phenyl)methanone (5). Synthesized following the procedure 3.4.1 to afford $0.173 \mathrm{~g}(6 \%)$ of a yellow viscous liquid, after column chromatography. ${ }^{1} \mathrm{H}-\mathrm{NMR}: \delta 8.00\left(\mathrm{~d}, 2 \mathrm{H},{ }^{3} \mathrm{~J}=8.0\right.$, $\mathrm{H}-8), 7.56\left(\mathrm{t}, 1 \mathrm{H},{ }^{3} \mathrm{~J}=7.5, \mathrm{H}-10\right), 7.46\left(\mathrm{t}, 2 \mathrm{H},{ }^{3} \mathrm{~J}=7.4, \mathrm{H}-9\right), 6.06(\mathrm{~s}, 1 \mathrm{H}, \mathrm{H}-4), 2.63,2.25(\mathrm{~s}, 3 \mathrm{H}$ each, 2CH 3$)$. ${ }^{13}$ C-NMR: $\delta 168.7$ (C-7), 152.4 (C-3), 145.3 (C-5), 132.7 (C-10), 131.6 (C-8), 128.1 (C-9), 111.4 (C-4), 14.6, $14.1\left(2 \mathrm{CH}_{3}\right)$. IR (neat, $\left.v / \mathrm{cm}^{-1}\right): 1694(\mathrm{C}=\mathrm{O}), 1583(\mathrm{C}=\mathrm{C}), 1448\left(\mathrm{CH}_{3}\right)$. MS (\%): $200.9(\mathrm{M}+, 7.5), 172.0$ (11.3), 104.9 (100), 76.9 (45.0), $51.0(20)$.

4-(3,5-Dimethyl-1H-pyrazol-1-yl)benzaldehyde (6). Synthesized following procedure 3.4.1 to afford $0.343 \mathrm{~g}$ $(10 \%)$ of a yellow viscous liquid after column chromatography. ${ }^{1} \mathrm{H}-\mathrm{NMR}: \delta 10.04(\mathrm{~s}, 1 \mathrm{H}, \mathrm{CHO}), 7.97$ $\left(\mathrm{d}, 2 \mathrm{H},{ }^{3} \mathrm{~J}=8.34, \mathrm{H}-8\right), 7.67\left(\mathrm{~d}, 2 \mathrm{H},{ }^{3} \mathrm{~J}=8.1, \mathrm{H}-7\right), 6.06(\mathrm{~s}, 1 \mathrm{H}, \mathrm{H}-4), 2.41,2.31$ (s, 3H each, 2CH$)^{2}$. ${ }^{13}$ C-NMR: $\delta 191.4$ (C-10), 150.5 (C-9), 145.0 (C-5), 140.0 (C-6), 134.5 (C-3) 130.9 (C-8), 124.1 (C-7), 108.9 (C-4), 13.8, $13.2\left(2 \mathrm{CH}_{3}\right)$. IR (neat, v/ $\left.\mathrm{cm}^{-1}\right)$ : $1697(\mathrm{C}=\mathrm{O}), 1555(\mathrm{C}=\mathrm{C}), 1514(\mathrm{Car}), 1418\left(\mathrm{CH}_{3}\right) . \mathrm{MS}(\%)$ : $200.3(\mathrm{M}+, 27.5), 199.9(100), 170.9(11.3), 129.9$ (17.5), $76.9(20)$.

\subsection{Temperature Effects Experiments}

Four ampoules containing $1.000 \mathrm{~g}$ of $\mathrm{Pz}^{\mathrm{Me} 2}(10.4 \mathrm{mmol})$, previously ground in a mortar, and $0.250 \mathrm{~mL}$ of $\mathrm{PhCCl}_{3}(1.7 \mathrm{mmol})$ each were cooled at $-30{ }^{\circ} \mathrm{C}$ and sealed under vacuum. The reference ampoule was introduced into a preheated oven at $80^{\circ} \mathrm{C}$ and heated at the same temperature for $24 \mathrm{~h}$. The other three ampoules were heated in two steps of temperature at 80/100, 80/120 and 80/160 ${ }^{\circ} \mathrm{C}$ for $24 \mathrm{~h}$ at each temperature. The obtained viscous reaction mixtures were dissolved in $30 \mathrm{~mL}$ of $\mathrm{CHCl}_{3}$ to homogenize and the solvent was evaporated to dryness, except the last ampoule whose content was homogenized by grinding it in a mortar. Samples of $10 \mathrm{mg} / \mathrm{mL}$ in methanol as solvent were prepared and then diluted to achieve $2.5 \mathrm{mg} / \mathrm{mL}$ for HPLC measurements. Chromatograms were recorded with $10 \mu \mathrm{L}$ of each sample eluted in the same conditions as the calibration curve. Calibration curves were obtained from methanol solutions of 2.0, 1.5, 1.0 and $0.5 \mathrm{mg} / \mathrm{mL}$ of compounds $1 \mathrm{a}-4$ each.

\subsection{Time Effect Experiments}

Three ampoules were prepared as described for temperature effects but starting with $5.00 \mathrm{~g}$ of $\mathrm{Pz}^{\mathrm{Me} 2}(52.0 \mathrm{mmol})$ and $1.23 \mathrm{~mL}$ of $\mathrm{PhCCl}_{3}(8.66 \mathrm{mmol})$ each, and heated in an oven at $120{ }^{\circ} \mathrm{C}$ for one, two and three days. The samples for HPLC were prepared as before.

\section{Conclusions}

In summary, the solventless synthesis of tris(pyrazolyl)phenylmethane ligands $\mathrm{C}_{6} \mathrm{H}_{5} \mathrm{C}\left(\mathrm{Pz}^{\mathrm{R} 2}\right)_{3}$ $(\mathrm{R}=\mathrm{H}, \mathrm{Me})$, starting from $\mathrm{PhCCl}_{3}$ and 3,5-dimethylpyrazole $\left(\mathrm{Pz}^{\mathrm{Me} 2}\right)$ or pyrazole $(\mathrm{Pz})$ was achieved. The sterically crowded $\mathrm{C}_{6} \mathrm{H}_{5} \mathrm{C}\left(\mathrm{Pz}^{\mathrm{Me} 2}\right)_{3}$ is labile due to both steric and electronic reasons; therefore it is thermally transformed at $120{ }^{\circ} \mathrm{C}$ into bis(pyrazolyl)(p-pyrazolyl)phenylmethane ligand, $\mathrm{Pz}^{\mathrm{Me} 2}-\mathrm{C}_{6} \mathrm{H}_{4} \mathrm{CH}\left(\mathrm{Pz}^{\mathrm{Me} 2}\right)_{2}$. In this compound both $\mathrm{Pz}^{\mathrm{Me} 2}$ rings are linked through the $\mathrm{N}$-atom to the methine-bridge $\mathrm{C}$-atom. At longer times of reaction or at temperatures beyond $120{ }^{\circ} \mathrm{C}$, the binding mode of $\mathrm{Pz}{ }^{\mathrm{Me} 2}$ changes from N1 to $\mathrm{C} 4$. Reaction conditions were established to obtain compound 1a in $30 \%, \mathbf{1 b}$ in $55 \%, \mathbf{2}$ in $70 \%, 3$ in $27 \%$ and $\mathbf{4}$ in $14 \%$ yields. The structures were proposed on the basis of 
${ }^{1} \mathrm{H}$ - and ${ }^{13} \mathrm{C}-\mathrm{NMR}$ spectroscopy and single crystal $\mathrm{X}$-ray diffraction. The three $\mathrm{Pz}^{\mathrm{Me} 2}$ rings, in compounds $\mathbf{1 a}$ and $\mathbf{1 b}$, adopt a three-bladed propeller structure around the axial phenyl ring. Comparison to the structures of other tris(pyrazolyl)phenylmethane ligands allowed to conclude that steric effects determine the conformation adopted by pyrazole rings: $(s p+2 a c)$ in the most crowded and $(2 s p+a p)$ in the less crowded compounds. Substituents in the pyrazole rings exert more steric demand than those located in the apical carbon atom.

Supplementary Materials: Supplementary materials are available online.

Acknowledgments: This work was supported by CONACYT grant 2551354, SIP-IPN grant 20160261 (Secretaría de Investigación y Postgrado del Instituto Politécnico Nacional), CGIC-UC (Coordinación General de Investigación Científica de la Universidad de Colima) and PROMEP-SEP. Authors thanks María de Jesús Rosales-Hoz for the X-ray diffraction data of compounds $\mathbf{1 b}$ and 2.

Author Contributions: E.R.-V. performed the experiments; E.R.-V., I.I.P.-M. designed the experiments and analyzed the data; E.R.-V., I.I.P.-M. and A.C. wrote the paper; E.V.G.-B. analyzed the X-ray diffraction data; F.J.M.-M. contributed the X-ray diffraction data of 2, EA and MS; I.I.P.-M. and F.J.M.-M. conceived and conducted the study.

Conflicts of Interest: The authors declare no conflict of interest.

\section{References}

1. Scorpionates, T.S. The Coordination Chemistry of Polypyrazolylborate Ligands; Imperial College Press: London, UK, 1999.

2. Trofimenko, S. Recent advances in poly(pyrazolyl)borate (scorpionate) chemistry. Chem. Rev. 1993, 93, 943-980. [CrossRef]

3. Muñoz-Hernández, M.A.; Montiel-Palma, V. Polypyrazolates of the heavier group 13 and 14 elements: A review. Inorg. Chim. Acta 2009, 362, 4328-4339. [CrossRef]

4. Trofimenko, S. Boron-Pyrazole Chemistry. J. Am. Chem. Soc. 1966, 88, 1842-1844. [CrossRef]

5. Semeniuc, R.F.; Reger, D.L. Metal Complexes of Multitopic, Third Generation Poly(pyrazolyl)methane Ligands: Multiple Coordination Arrangements. Eur. J. Inorg. Chem. 2016, 2253-2271. [CrossRef]

6. Bigmore, H.R.; Sally, C.; Mountford, L.P.; Tredget, C.S. Coordination, organometallic and related chemistry of tris(pyrazolyl)methane ligands. Dalton Trans. 2005, 4, 635-651. [CrossRef] [PubMed]

7. Otero, A.; Fernández-Baeza, J.; Antiñolo, A.; Tejeda, J.; Lara-Sánchez, A. Heteroscorpionate ligands based on bis(pyrazol-1-yl)methane: Design and coordination chemistry. Dalton Trans. 2004, 10, 1499-1510. [CrossRef] [PubMed]

8. Otero, A.; Fernández-Baeza, J.; Lara-Sanchez, A.; Tejeda, J.; Sanchez-Barba, L.F. Microreview: Recent Advances in the Design and Coordination Chemistry of Heteroscorpionate Ligands Bearing Stereogenic Centres. Eur. J. Inorg. Chem. 2008, 5309-5326. [CrossRef]

9. Otero, A.; Fernández-Baeza, J.; Lara-Sánchez, A.; Sánchez-Barba, L.F. Metal complexes with heteroscorpionate ligands based on the bis(pyrazol-1-yl)methane moiety: Catalytic Chemistry. Coord. Chem. Rev. 2013, 257, 1806-1868. [CrossRef]

10. Padilla-Martínez, I.I.; Poveda, M.L.; Carmona, E.; Monge, M.A.; Ruiz-Valero, C. Synthesis and Reactivity of $\left[\operatorname{Ir}\left(\mathrm{C}_{2} \mathrm{H}_{4}\right)_{2} \mathrm{TpmMe}_{2}\right] \mathrm{PF}_{6}\left(\mathrm{TpmMe}_{2}=\right.$ Tris(3,5-dimethylpyrazolyl)methane): Comparison with the Analogous $\mathrm{TpMe}_{2}$ Derivatives (TpMe $=$ Hydrotris(3,5-dimethylpyrazolyl)borate). Organometallics 2002, 21, 93-104. [CrossRef]

11. Hernández-Juárez, M.; Salazar, V.; Padilla-Martínez, I.I.; García-Báez, E.V. Carbonyl-carbonyl and carbonyl- $\pi$ interactions as directing motifs in the supramolecular structure of carbonyl(3-oxopenta-1, 4-diene-1,5-diyl)[tris(3,5-di-methyl-1H-pyrazol-1-yl-kN2)methane]iridium(III) trifluoromethanesulfonate. Acta Crystallogr. Sect. C Cryst. Struct. Commun. 2012, 68, m367-m369. [CrossRef] [PubMed]

12. Hernández-Juárez, M.; Salazar, V.; García-Báez, E.V.; Padilla-Martínez, I.I.; Höpfl, H.; Rosales-Hoz, M.J. Synthesis and Crystal Structure of Iridium-1,4-benzoquinone Complexes of Tris(3,5-dimethylpyrazolyl) methane Ligand: Decarbonylation, Protonation and Substitution Reactions. Organometallics 2012, 31, 5439-5451. [CrossRef] 
13. Cushion, M.G.; Meyer, J.; Heath, A.; Schwarz, A.D.; Fernandez, I.; Breher, F.; Mountford, P. Syntheses and Structural Diversity of Group 2 and Group 12 Tris(pyrazolyl)methane and Zwitterionic Tris(pyrazolyl)methanide Compounds. Organometallics 2010, 29, 1174-1190. [CrossRef]

14. Manzano, B.R.; Jalón, F.A.; Carrión, M.C.; Durá, G. Bis(pyrazol-1-yl)(pyridin-x-yl)methane Ligands-Monoor Ditopic Ligands in Complexes and Supramolecular Frameworks. Eur. J. Inorg. Chem. 2016, 2272-2295. [CrossRef]

15. Wang, L.; Chambron, J.-C. Synthesis of a Macrobicycle Incorporating the Tris(pyrazolyl)methane Ligand. Org. Lett. 2004, 6, 747-750. [CrossRef] [PubMed]

16. Bassanetti, I.; Comotti, A.; Sozzani, P.; Bracco, S.; Calestani, G.; Mezzadri, F.; Marchio, L. Porous Molecular Crystals by Macrocyclic Coordination Supramolecules. J. Am. Chem. Soc. 2014, 136, 14883-14895. [CrossRef] [PubMed]

17. Martins, L.M.D.R.S.; Pombeiro, A.J.L. Water-Soluble C-Scorpionate Complexes-Catalytic and Biological Applications. Eur. J. Inorg. Chem. 2016, 2236-2252. [CrossRef]

18. García, R.; Paulo, A.; Santos, I. Rhenium and technetium complexes with anionic or neutral scorpionates: An overview of their relevance in biomedical applications. Inorg. Chim. Acta 2009, 362, 4315-4327. [CrossRef]

19. Zhang, J.; Li, A.; Hor, T.S.A. Ligand effect on ethylene trimerisation with [NNN]-heteroscorpionate pyrazolyl Cr(III) catalysts. Dalton Trans. 2009, 42, 9327-9333. [CrossRef] [PubMed]

20. Julia, S.; del Mazo, J.M.; Avila, L.; Elguero, J. Improved synthesis of polyazolylmethanes under solid-liquid phase-transfer catalysis. Org. Prep. Proced. Int. 1984, 16, 299-307. [CrossRef]

21. Reger, D.L.; Grattan, T.C.; Brown, K.J.; Little, C.A.; Lamba, J.J.S.; Rheingold, A.L.; Sommer, R.D. Syntheses of tris(pyrazolyl)methane ligands and $\{$ tris(pyrazolyl)methane $\left.] \mathrm{Mn}(\mathrm{CO})_{3}\right\} \mathrm{SO}_{3} \mathrm{CF}_{3}$ complexes: Comparison of ligand donor properties. J. Organomet. Chem. 2000, 607, 120-128. [CrossRef]

22. Fujisawa, K.; Ono, T.; Aoki, H.; Ishikawa, Y.; Miyashita, Y.; Okamoto, K.-I.; Nakazawa, H.; Higashimura, H. Copper(II) complexes with a novel tris(3,5-diisopropyl-1-pyrazolyl)methane ligand, $\left[\mathrm{Cu}\left(\mathrm{X}_{2}\right)\left\{\mathrm{HC}\left(3,5-{ }^{\mathrm{i}} \mathrm{Pr}_{2} \mathrm{pz}\right)_{3}\right\}\right]\left(\mathrm{X}=\mathrm{Cl}\right.$ and $\left.\mathrm{NO}_{3}\right)$. Inorg. Chem. Commun. 2004, 7, 330-332. [CrossRef]

23. Reger, D.L.; Grattan, T.C. Synthesis of Modified Tris(pyrazolyl)methane Ligands: Backbone Functionalization. Synthesis 2003, 350-356. [CrossRef]

24. Goodman, M.S.; Bateman, M.A. Synthesis of tris(pyrazolyl)methanes of unprecedented complexity and functionality. Tetrahedron Lett. 2001, 42, 5-7. [CrossRef]

25. Liddle, B.J.; Gardinier, J.R. A Practical Synthesis of Tris(pyrazolyl)methylaryls. J. Org. Chem. 2007, 72, 9794-9797. [CrossRef] [PubMed]

26. Krieck, S.; Koch, A.; Hinze, K.; Müller, C.; Lange, J.; Görls, H.; Westerhausen, M. s-Block Metal Complexes with Bis- and Tris(pyrazolyl)methane and -methanide Ligands. Eur. J. Inorg. Chem. 2016, 15-16, 2332-2348. [CrossRef]

27. Zhang, X.-M. Hydro(solvo)thermal in situ ligand syntheses. Coord. Chem. Rev. 2005, 249, 1201-1219. [CrossRef]

28. Lupacchini, M.; Mascitti, A.; Giachi, G.; Tonucci, L.; d'Alessandro, N.; Martinez, J.; Colacino, E. Sonochemistry in non-conventional, green solvents or solvent-free reactions. Tetrahedron 2017, 73, 609-653. [CrossRef]

29. Do, J.-L.; Friščić, T. Mechanochemistry: A Force of Synthesis. ACS Cent. Sci. 2017, 3, 13-19. [CrossRef] [PubMed]

30. Jacob, J. Microwave Assisted Reactions in Organic Chemistry: A Review of Recent Advances. Int. J. Chem. 2012, 4, 29-43. [CrossRef]

31. Escobedo, R.; Miranda, R.; Martínez, J. Infrared Irradiation: Toward Green Chemistry, a Review. Int. J. Mol. Sci. 2016, 17, 453. [CrossRef] [PubMed]

32. Humphrey, E.R.; Mann, K.L.V.; Reeves, Z.R.; Behrendt, A.; Jeffery, J.C.; Maher, J.P.; McCleverty, J.A.; Ward, M.D. Copper(II) complexes of new potentially hexadentate $\mathrm{N}_{3} \mathrm{~S}_{3}$ - or $\mathrm{N}_{6}$-donor podand ligands based on the tris(pyrazolyl)borate or tris(pyrazolyl)methane core. New J. Chem. 1999, 23, 417-423. [CrossRef]

33. García-Sánchez, A.; Padilla-Martínez, I.I.; Martínez-Martínez, F.J.; Höpfl, H.; García-Báez, E.V. 1,1,2,2-Tetrachloro-1,2-diphenylethane. Acta Crystallogr. Sect. E Struct. Rep. 2005, 61, o678-o680. [CrossRef] 
34. Seidel, F.; Their, W.; Uber, A.; Dittmer, J. Über die Bildung des Triacetyl-essigesters (II. Mitteil.). Eur. J. Inorg. Chem. 1935, 68, 1913-1924. [CrossRef]

35. Artico, M.; Silvestri, R.; Stefancich, G.; Avigliano, L.; di Giulio, A.; Maccarrone, M.; Agostinelli, E.; Mondovi, B.; Morpurgo, L. Aromatic hydrazides as specific inhibitors of bovine serum amine oxidase. Eur. J. Med. Chem. 1992, 27, 219-228. [CrossRef]

36. Liao, P.-Q.; He, C.-T.; Zhou, D.-D.; Zhang, J.-P.; Chen, X.-M. Porous Metal Azole Frameworks. In The Chemistry of Metal-Organic Frameworks: Synthesis, Characterization, and Applications; Kaskel, S., Ed.; Wiley VCH: Weinheim, Germany, 2016; Volume 1, pp. 309-338.

37. Cook, L.J.K.; Kearsey, R.; Lamb, J.V.; Pace, E.J.; Gould, J.A. Efficient and chromatography-free methodology for the modular synthesis of oligo-(1H-pyrazol-4-yl)-arenes with controllable size, shape and steric bulk. Tetrahedron Lett. 2016, 57, 895-898. [CrossRef]

38. Sanjeev, R.; Jagannadham, V. Substituent effects on the spontaneous cleavage of benzyl-gem-dichlorides in aqueous solution. Indian J. Chem. Sect. B Org. Chem. Incl. Med. Chem. 2002, 41B, 2145-2149.

39. Merga, G.; Aravindakumar, C.T.; Rao, B.S.M.; Mohan, H.; Mittal, J.P. Pulse radiolysis study of the reactions of $\mathrm{SO}_{4}{ }^{-}$with some substituted benzenes in aqueous solution. J. Chem. Soc. Faraday Trans. 1994, 90, 597-604. [CrossRef]

40. Jude, H.; Rein, F.N.; Chen, W.; Scott, B.L.; Dattelbaum, D.M.; Rocha, R.C. Pyrazole and Pyrazolyl Complexes of cis-Bis(2,2'-bipyridine)chlororuthenium(II): Synthesis, Structural and Electronic Characterization and Acid-Base Chemistry. Eur. J. Inorg. Chem. 2009, 5, 683-690. [CrossRef]

41. AL-Attas, A.S.; Habeeb, M.M.; Al-Raimi, D.S. Synthesis and spectroscopic studies of charge transfer complexes between chloranilic acid and some heterocyclic amines in etanol. J. Mol. Struct. 2009, 928, 158-170. [CrossRef]

42. Ehlert, M.K.; Storr, A.; Thompson, R.C. Metal pyrazolate polymers. Part 3. Synthesis and study of $\mathrm{Cu}(\mathrm{I})$ and $\mathrm{Cu}(\mathrm{II})$ complexes of $4-\mathrm{Xdmpz}$ (where $\mathrm{X}=\mathrm{H}, \mathrm{Cl}, \mathrm{Br}, \mathrm{I}$, and $\mathrm{CH}_{3}$ for $\mathrm{Cu}(\mathrm{I})$ and $\mathrm{X}=\mathrm{H}, \mathrm{Cl}, \mathrm{Br}$, and $\mathrm{CH}_{3}$ for $\mathrm{Cu}(\mathrm{II}) ; \mathrm{dmpz}=3,5$-dimethylpyrazolate). Can. J. Chem. 1992, 70, 1121-1128. [CrossRef]

43. Allen, F.H.; Kennard, O.; Watson, D.G.; Brammer, L.; Orpen, A.G.; Taylor, R. Typical Interatomic Distances: Organic Compounds. International Tables for Crystallography; Wilson, A.J.C., Ed.; Kluwer Academic Publishers: Dordrecht, The Netherlands, 1992; Volume C, pp. 685-706.

44. Harding, D.J.; Harding, P.; Plant, S.E. Tris(5-methyl-3-phenyl-1H-pyrazol-1-yl)methane. Acta Crystallogr. Sect. E Struct. Rep. 2008, 64, o896. [CrossRef] [PubMed]

45. Ochando, L.E.; Rius, J.; Louer, D.; Claramunt, R.M.; Lopez, C.; Elguero, J.; Amigo, J.M. Phase Transitions in Tris(3,5-dimethylpyrazol-1-yl)methane. The Structure of the High-Temperature Phase from X-ray Powder Diffraction. Acta Crystallogr. Sect. B Struct. Sci. 1997, 53, 939-944. [CrossRef]

46. Declercq, J.-P.; Van Meerssche, M. Tris(3,5-dimethyl-1-pyrazolyl)methane, $\mathrm{C}_{16} \mathrm{H}_{22} \mathrm{~N}_{6}$. Acta Crystallogr. Sect. C Cryst. Struct. Commun. 1984, 40, 1098-1101. [CrossRef]

47. Chen, X.-Y.; Yang, X.; Holliday, B. J. 1,1',1"-\{[4-(3,4-Ethylenedioxythiophen-2-yl)phenyl]methanetriyl\}tris (1H-pyrazole). Acta Cryst. Sect. 2011, 67, o3021. [CrossRef] [PubMed]

48. Chen, X.-Y.; Yang, X.; Holliday, B. J. 4-[Tris(1H-pyrazol-1-yl)methyl]phenol. Acta Crystallogr. Sect. E Struct. Rep. 2011, 67, o3045. [CrossRef] [PubMed]

49. Mclauchlan, C.C.; Smith, B.L.; Pippins, R.S.; Nelson, B.M. 2,2,2-Tris(pyrazol-1-yl)ethanol. Acta Crystallogr. Sect. E Struct. Rep. 2011, 67, o1133-o1134. [CrossRef] [PubMed]

50. Kerscher, T.; Pust, P.; Betz, R.; Klüfersand, P.; Mayer, P. Trispyrazol-1-ylmethane. Acta Crystallogr. Sect. E Struct. Rep. 2009, 65, o108. [CrossRef] [PubMed]

51. Bernstein, J.; Davis, R.E.; Shimoni, L.; Chang, N.-L. Patterns in hydrogen bonding: Functionality and graph set analysis in crystals. Angew. Chem. Int. Ed. Engl. 1995, 34, 1555-1573. [CrossRef]

52. Sheldrick, G.M. A short history of SHELX. Acta Crystallogr. Sect. A Found. Crystallogr. 2008, 64, 112-122. [CrossRef] [PubMed]

53. Farrugia, L.J. WinGX suite for small-molecule single-crystal crystallography. J. Appl. Crystallogr. 1999, 32, 837-838. [CrossRef] 
54. Macrae, C.F.; Edgington, P.R.; McCabe, P.; Pidcock, E.; Shields, G.P.; Taylor, R.; Towler, M.; van de Streek, J. Mercury: Visualization and analysis of crystal structures. J. Appl. Crystallogr. 2006, 39, 453-457. [CrossRef]

55. Spek, A.L. Single-crystal structure validation with the program PLATON. J. Appl. Crystallogr. 2003, 36, 7-13. [CrossRef]

Sample Availability: Samples of the compounds 1a, 1b, $\mathbf{2 - 4}$ are available from the authors. article distributed under the terms and conditions of the Creative Commons Attribution (CC BY) license (http:/ / creativecommons.org/licenses/by/4.0/). 